WATER RESOURCES OF THE FOND DU LAC INDIAN RESERVATION, EAST-CENTRAL MINNESOTA

James F. Ruhl

U.S. GEOLOGICAL SURVEY

Water-Resources Investigations Report 88-4114

Prepared in Cooperation with the

FOND DU LAC INDIAN RESERVATION BUSINESS COMMITTEE

St. Paul, Minnesota

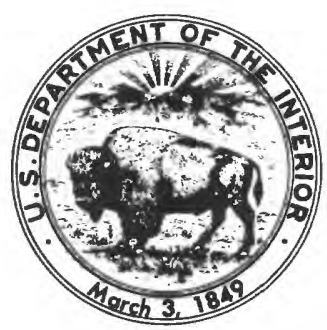


DEPARTMENT OF THE INTERIOR

MANUEL LUJAN, JR., Secretary

U.S. GEOLOGICAL SURVEY

Dallas L. Peck, Director

For additional information to:

District Chief

U.S. Geological Survey 702 Post Office Building

St. Paul, Minnesota 55101
Copies of this report can be purchased from:

U.S. Geological Survey Books and Open-File Reports Section Federal Center, Box 25425

Denver, Colorado 80225 


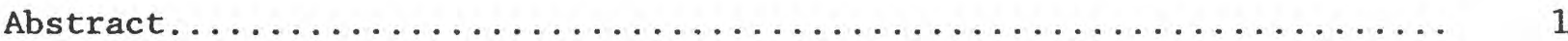

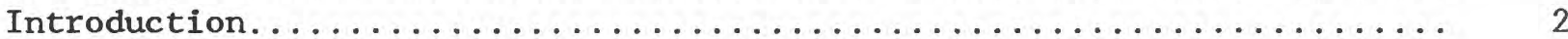

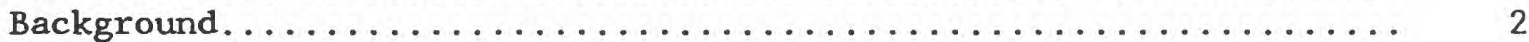

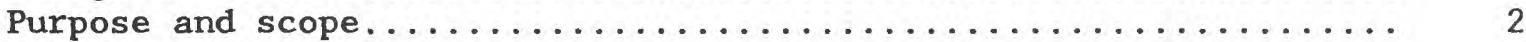

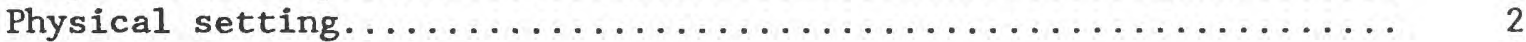

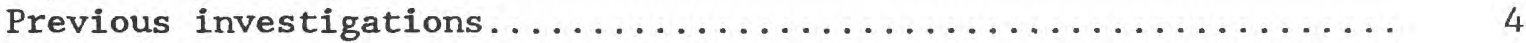

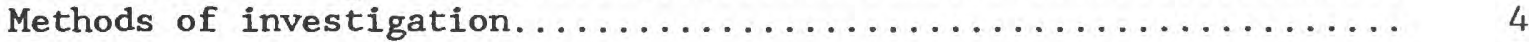

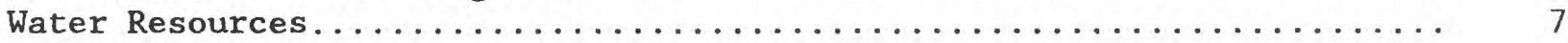

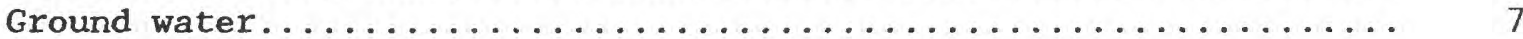

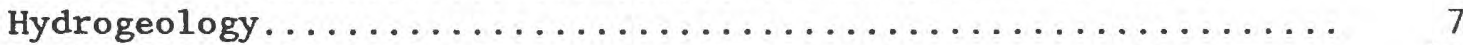

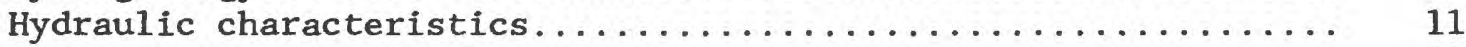

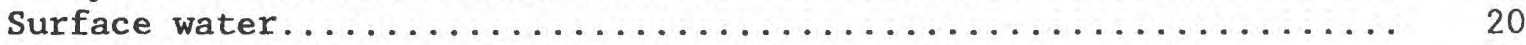

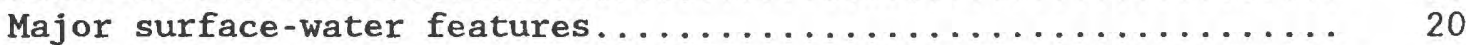

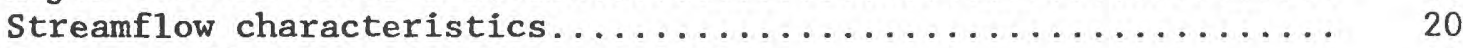

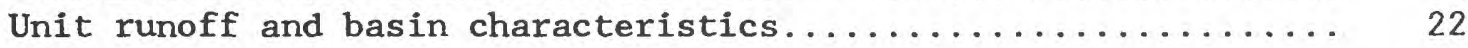

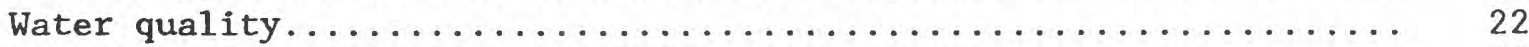

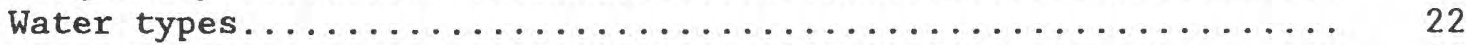

Quality of surface water for aquatic life and recreation....... 28

Quality of ground water for household supply............. 28

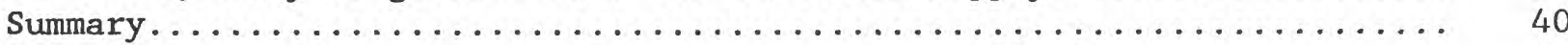

References.................................... 41

\section{ILLUSTRATIONS}

Figures 1-2. Maps showing:

1. Location of the Fond du Lac Indian Reservation....... 3

2. Surficial geology of the Fond du Lac Reservation.... 5

3. Graph showing annual precipitation at the weather station in the Fond du Lac Indian Reservation during water years

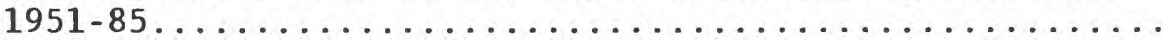

4. Map showing elevations of the top of the bedrock in the

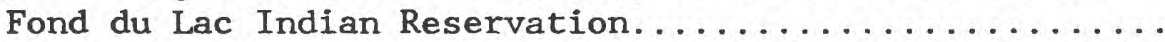

5. Generalized hydrogeologic section through the southeastern corner of the Fond du Lac Indian Reservation..........

6. Map showing thicknesses of glacial drift in the

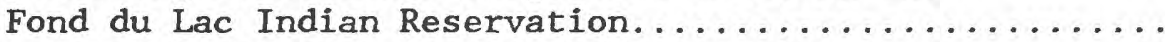

7. Graphs showing precipitation and water level in a representative well in the unconfined-drift aquifer in the Fond du Lac Indian Reservation for water years 1977 -

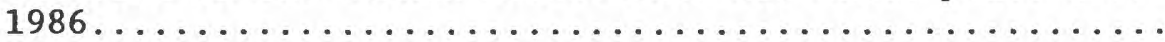


8-13. Maps showing:

8. Potentiometric surface and direction of ground-water flow in unconfined-drift aquifers in the

Fond du Lac Indian Reservation in summer $1983 \ldots .$.

9. Transmissivity of unconfined-drift aquifers in the

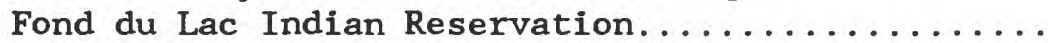

10. Transmissivity of confined-drift aquifers in the

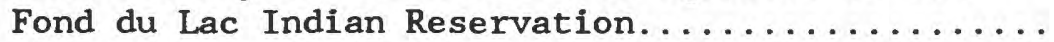

11. Estimated potential yield of wells completed in unconfined-drift aquifers in the Fond du Lac

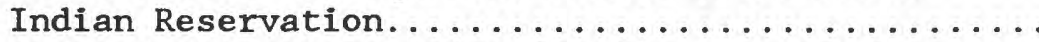

12. Estimated potential yield of wells completed in confined-drift aquifers in the Fond du Lac Indian

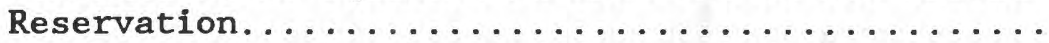

13. Basin boundaries in the Fond du Lac Indian

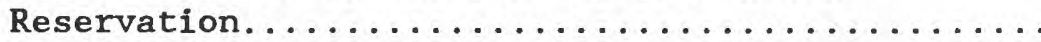

14. Graphs showing precipitation and discharge of four streams in the Fond du Lac Indian Reservation for the 1984 water

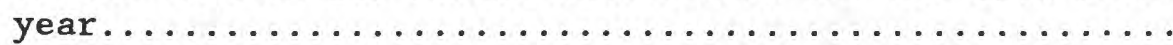

15. Trilinear diagram showing percent of total cation and anion concentrations in ground- and surface-water samples collected in the Fond du Lac Indian Reservation.

16-17. Stiff diagrams showing ion balance of selected samples collected from:

16. Wells completed in the unconfined-drift, confineddrift, and bedrock aquifers in the Fond du Lac

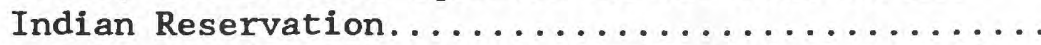

17. Big Lake and four streams in the Fond du Lac Indian

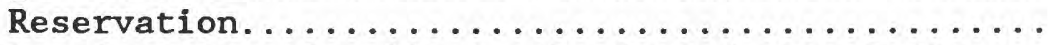

18. Map showing location of wells in the Fond du Lac Indian Reservation where concentrations of constituents exceed recommended limits and standards for drinking water established by the U.S. Environmental Protection Agency.

\section{TABLES}

Table 1. Summary of water-quality data for samples collected from Big Lake and four streams in the Fond du Lac Indian

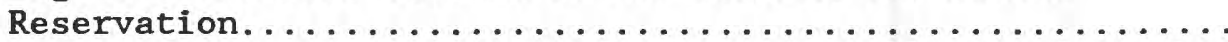

2. Summary of water-quality data for samples collected from the three principal aquifers in the Fond du Lac Indian

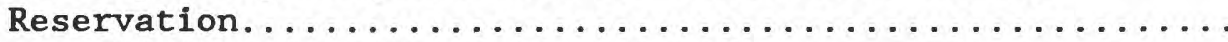

3. Recommended limits, standards, significance, and exceedance of limits and standards for common water-quality properties and constituents in samples collected from streams and aquifers in the Fond du Lac Indian Reservation........... 


\section{CONVERSION FACTORS AND ABBREVIATIONS}

Readers who prefer to use metric (International System) units rather than inch-pound units can make conversions using the following factors:

Multiply Inch-Pound Unit

foot (ft)
foot square per day
$\left(\mathrm{ft}^{2} / \mathrm{d}\right)$
cubic foot per second
$\quad\left(\mathrm{ft}^{3} / \mathrm{s}\right)$

ga1lon (ga1)

gallon per minute (gal/min)

inch (in)

acre

degree Fahrenheit $\left({ }^{\circ} \mathrm{F}\right)$
By

$$
0.3048
$$

0.09290

0.02832

3.785

0.06308

25.4

0.4047

${ }^{\circ} \mathrm{C}=5 / 9 \times\left({ }^{\circ} \mathrm{F}-32\right)$
To Obtain Metric Unit

$$
\begin{aligned}
& \text { meter (m) } \\
& \text { square meter per day } \\
& \left(\mathrm{m}^{2} / \mathrm{d}\right) \\
& \text { cubiç meter per second } \\
& \left(\mathrm{m}^{3} / \mathrm{s}\right) \\
& \text { liter (L) } \\
& \text { liter per second } \\
& \text { (L/s) } \\
& \text { millimeter (mm) } \\
& \text { hectare } \\
& \text { degree Celsius }\left({ }^{\circ} \mathrm{C}\right)
\end{aligned}
$$




\title{
WATER RESOURCES OF THE FOND DU LAC INDIAN RESERVATION, EAST-CENTRAL MINNESOTA
}

By James F. Ruh1

\begin{abstract}
Water resources in the Fond du Lac Indian Reservation meet the present (1987) needs for drinking-water supplies and other household uses with respect to water quality and quantity, and provide valuable ecological, recreational, and aesthetic benefits. Total annual water use in the Reservation is about 36.5 million gallons per year and per capita use is about 100 gallons per day. Practically all the water is used for domestic supply. Ground water is the source of all water supplies in the Reservation.

Three aquifers are the source of ground water in the Reservation. Unconfined-drift aquifers consist of surficial outwash that extends over one third of the Reservation. Confined-drift aquifers consist of sand and gravel deposits that occur discontinuously at depths of 50 to 150 feet throughout the Reservation. The third aquifer is in crystaline bedrock that underlies the glacial drift.

Surface-water resources in the Reservation consist of numerous wetlands, many shallow lakes, and streams that drain five basins. All the basins in the Reservation are part of the St. Louis River drainage system, except for a small area in the southcentral part of the Reservation that is part of the Kettle River basin. Stoney Brook, which is the major stream, drains three fourths of the Reservation. Average discharge from Stoney Brook during the 1984 water year was 82 cubic feet per second. The lakes in the Reservation, which are shallow and small, have a combined surface area of about 3,000 acres.

Concentrations of constituents in ground-water samples met recommended and regulated limits set by the U.S. Environmental Protection Agency for drinking water except for samples collected from wells in the unconfined-drift aquifer that suggested limits for nitrate (one sample), iron (two samples), and manganese (six samples), were exceeded. Quality of water in the lakes and streams is suitable for native forms of plant and animal life.
\end{abstract}




\section{Background}

This report presents the findings of a water-resources study of the Fond du Lac Indian Reservation. The study is the outcome of a 1978 Federal mandate to the Bureau of Indian Affairs to review Indian water-rights claims in reservations throughout the United States. The Fond du Lac Indian Reservation study, done by the U. S. Geological Survey in cooperation with the Fond du Lac Indian Reservation Business Committee, is the first of the these studies undertaken in Minnesota under the Federal mandate.

\section{Purpose and Scope}

This report describes the water resources of the Fond du Lac Indian Reservation. The objectives of the study were to (1) estimate water use, (2) describe the areal extent and thickness of the unconfined-drift aquifers, (3) determine the hydraulic properties of the aquifers, (4) describe the groundwater flow system, (5) estimate the streamflow characteristics for a typical water year, and (6) assess the quality of the surface and ground water.

Population data for the Reservation and average per capita water use for rural Minnesota served as a basis for estimation of water use. Eleven test holes were drilled and about 50 drillers' logs were interpreted to describe the hydrogeology. Water-level measurements were made in 25 wells to determine flow directions in the glacial-drift and bedrock aquifers. Discharge data were collected from gaging stations on four streams to assess flow characteristics for a typical water year. Quality of the ground and surface water was evaluated on the basis of analyses of samples collected from fifteen wells, four streams, and one lake.

\section{Physical Setting}

The Fond du Lac Indian Reservation, located in east-central Minnesota (fig. 1), covers about 100,000 acres. About three fourths of the Reservation is forest, consisting mainly of aspen/birch in upland areas and black spruce in lowland peat bogs. Roughly 10 percent of the Reservation land is pasture and open space, and another 15 percent is residential, commercial/industrial, or agricultural (Arrowhead Regional Development Commission, 1981).

The landscape is flat to gently rolling, particularly in the outwash plains and peat bogs that extend across much of the southern part of the Reservation. The topography in these areas contrasts with the more hilly morainal areas in the northern part, where the relief is as much as $200 \mathrm{feet}$.

Soils in the Reservation range from moderately well- to poorly drained loamy soils in the morainal areas to well-drained sandy and gravelly soils in the outwash plains. The morainal areas extend across one third of the area in the central and northern parts. Outwash plains extend over another third of 


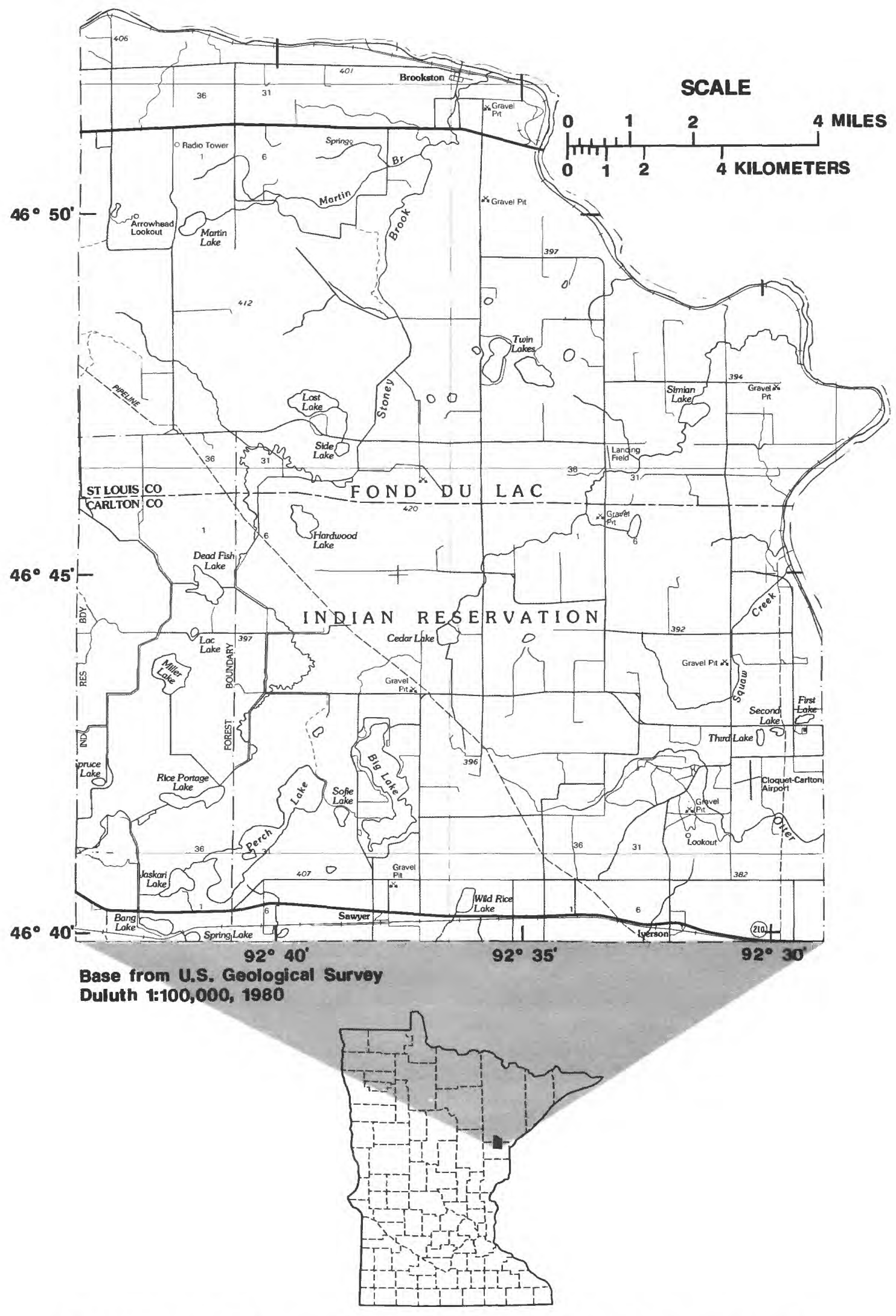

FIGURE 1.--Location of the Fond du Lac Indian Reservation. 
the Reservation, mainly in the southeastern part (fig. 2). Peatland soils, which consist of poorly drained organic matter, occur in many areas in the Reservation.

The Reservation occupies a continental climatic zone, where temperature and precipitation vary widely (fig. 3). During the 1984 water year, when the precipitation was a normal 31 inches, runoff from the Reservation was 12 inches and evapotranspiration, estimated as the residual, was 19 inches.

Total annual water use on the Reservation is about 36.5 million gallons per year. This estimate is based on the estimated amount of water used by the rural population of Minnesota (1,150,000 people) for domestic purposes and the estimated population of the Reservation (1,000 people) (Solley and others, 1983; and Arrowhead Regional Development Commission, 1981). The daily per capita use determined from these assumptions is slightly more than 100 gallons per day.

\section{Previous Investigations}

Winchell (1899) first described the geology of the area in general terms, and later Leverett $(1929,1932)$ described the glacial geology. Schwartz (1949), Wright (1956), Wright and others (1970), Morey and Ojakangas (1970), Sims and Morey (1972), and Wright (1973) all described specific geologic features in the area in greater detail. Thiel (1947), who studied specific geological features, evaluated the water resources of the area. He identified the aquifers tapped for municipal water supply and provided water-quality data for samples collected from four supply wells used by the city of Cloquet, which is about two miles east of the Reservation. Akin and Jones (1952) carried out a more detailed hydrogeologic study for cloquet. Their area of study included the southeastern corner of the Reservation. Lindholm and others (1979) summarized the climate, hydrogeology, surface-water resources, and water quality of the St. Louis River watershed, which includes most of the Fond du Lac Indian Reservation. Myette (1985) recently completed a groundwater study of surficial outwash aquifers in east-central Minnesota that includes the southern half of the Reservation.

\section{Methods of Investigation}

A literature survey provided the basis for a preliminary evaluation of the study area. A wide range of published materials, including many of those cited in the previous section, provided information about the climate, soils, geology, hydrogeology, surface water, and water quality. Additional data on the hydrogeology, streamflow characteristics, and water quality were collected in the field during the course of this study.

Geologic data from 11 test holes provided detailed information about the thickness and lithology of the glacial drift. Eight of the test holes penetrated glacial till down to the bedrock surface. Only three of the test holes penetrated units of confined sand and gravel. Observation wells were installed in these holes with the screens set in the confined sand and gravel. 

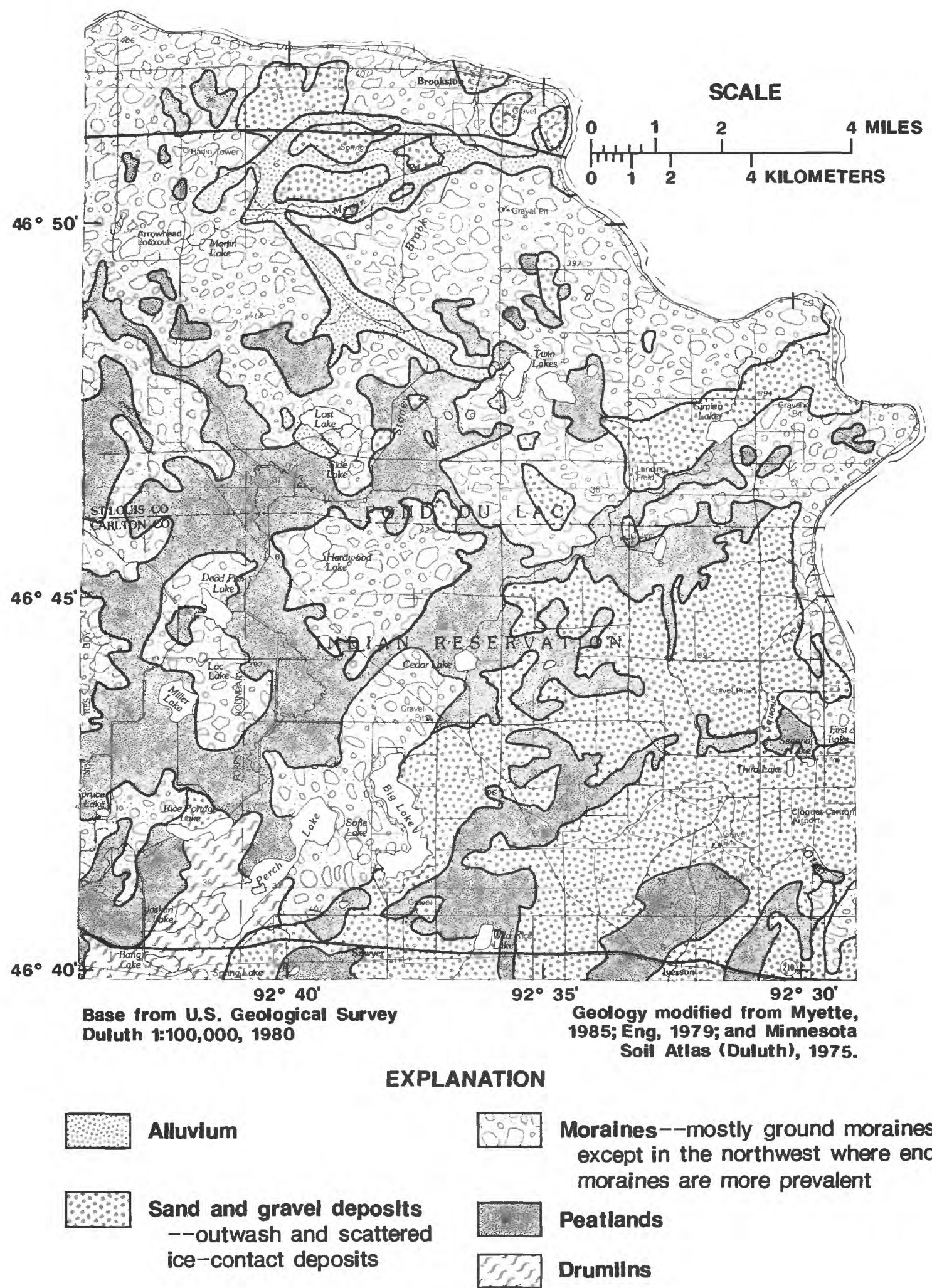

Moraines--mostly ground moraines except in the northwest where end moraines are more prevalent

Peatlands

--outwash and scattered ice-contact deposits

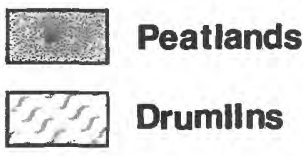

FIGURE 2.--Surficial geology of the Fond du Lac Reservation. 


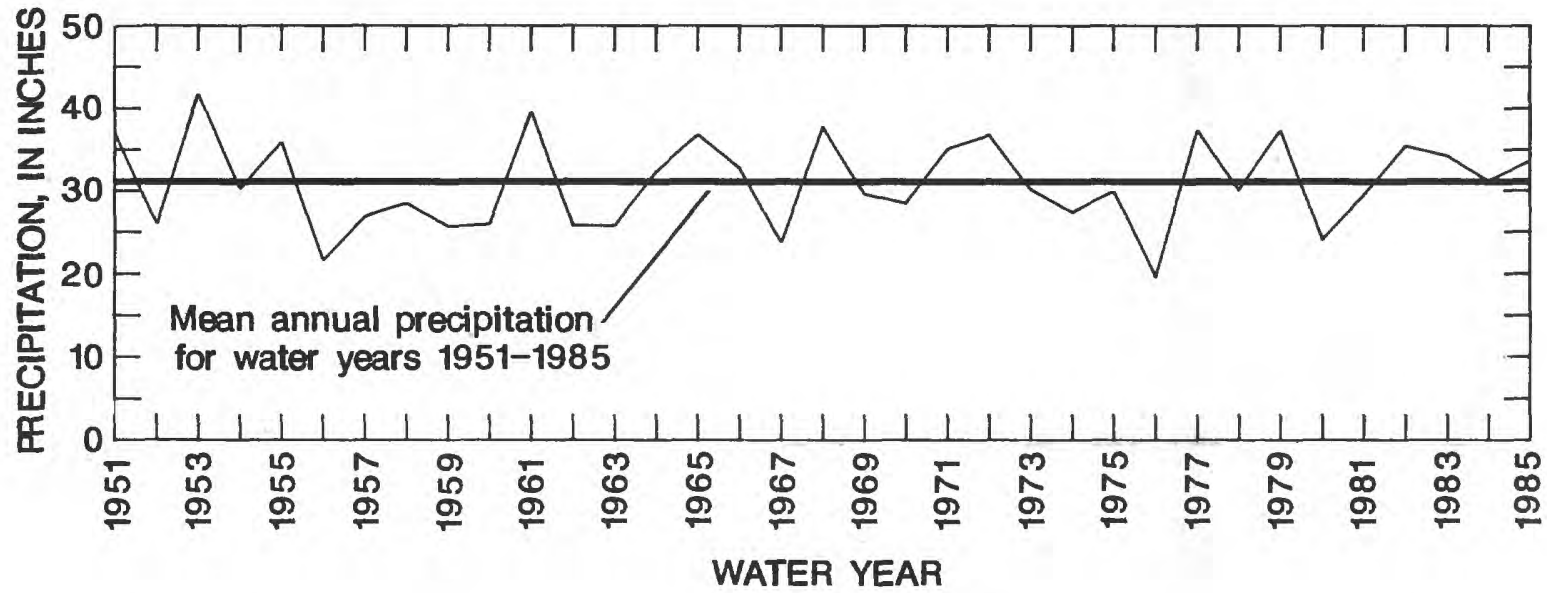

FIGURE 3.--Annual precipitation at the weather station in the Fond du Lac Indian Reservation during water years 1951-85. 
Water-level data were collected from a total of 23 wells. Ten of these wells were installed during an earlier study (Myette, 1985) in the unconfined-drift aquifers and were used only for observation. Eight wells (five of these are domestic wells and the other three are the observation we11s referred to in the previous paragraph) were completed in confined-drift aquifers, and five were completed in the bedrock aquifer. Water-quality samples were collected from a total of 15 wells--5 eachfrom wells completed in unconfined-drift, confined-drift, and bedrock aquifers.

Evaluation of the hydraulic properties of the aquifers is based on several sources of information. Transmissivities were estimated from: (1) an aquifer test carried out in a previous study; (2) evaluation of aquifer materials during drilling operations; and (3) the specific capacity of wells determined from commercial well-drillers' logs.

Stage-discharge data were collected at gaging stations on four streams that drain the Reservation. Automatic recorders installed at each of the stations continuously measured stage and U.S. Geological Survey personnel measured the discharge approximately once a month. Slightly more than one year of stream-discharge data were collected at each of the sites. Waterquality samples also were collected from the sites using procedures established by the U.S. Geological Survey (Fishman and others, 1985; and Greeson and others, 1979).

\section{WATER RESOURCES}

\section{Ground Water}

\section{Hydrogeology}

Ground water is the source of all water supplies in the Reservation. This report categorizes and describes the hydrogeologic units that are tapped for ground-water supplies into three types of aquifers: (1) unconfined-drift aquifers; (2) confined-drift aquifers; and (3) the bedrock aquifer. The glacial-drift aquifers consist of permeable deposits of sand and gravel. The unconfined-drift aquifers consist of surficial outwash that extends across the southeastern part of the Reservation. The confined-drift aquifers consist of sand and gravel deposits buried in the deeper drift below less-permeable layers of clay or till. The bedrock aquifer underlies the glacial drift throughout the Reservation at depths that range from 20 to 260 feet below land surface.

The bedrock, known as the Thomson Formation, is a metasedimentary unit of Proterozoic age that contains layers of slightly to moderately metamorphosed slate, graywacke, and siltstone. The estimated thickness of the formation ranges from 3,000 to 20,000 feet (Morey and 0jakangas, 1970). Exposures of the formation reveal many minor folds (Wright and others, 1970). Elevations of the top the bedrock indicate considerable relief, particularly in the central and southeastern parts (fig 4). The relief may be due in part to glacial erosion, but is more likely due to structural deformation caused by stresses in the bedrock.

Slate is the dominant lithology in the Thomson Formation. Individual slate beds are as much as 60 feet thick, and sequences of slate beds are as 
much as 500 feet thick (Morey and 0jakangas, 1970). The upper layer of the Thomson Formation consists of a weathered zone that has a soft, smooth consistency. The thickness of this zone generally ranges from a few feet to 50 feet. The color ranges from green to dark gray.

Most wells completed in the bedrock aquifer are in the southeastern part of the Reservation, although several are in the northern part. The depth of bedrock we11s ranges from 100 to 500 feet. Uncased intervals for these bedrock wells range from 20 to 300 feet, depending on the density and depth of water-bearing fractures. Confined conditions occur in the bedrock aquifer due to the very low permeability of the weathered surface of the bedrock and of the overlying till. The hydrogeologic section schematically shows the water level in bedrock wells as much as 100 feet above the top of the aquifer ( $\mathrm{fig}$. 5). Water in the bedrock aquifer discharges to the St. Louis River (fig. 5).

Glacial drift in the Reservation consists mostly of outwash and till. The outwash consists of stratified sand and gravel that occurs mainly in the southeastern part of the Reservation (fig. 2). Till consists of unstratified, unsorted clay- to boulder-sized materials. Glacial drift in the morainal areas consists predominantly of till. Test drilling showed the thickness of the drift in the Reservation ranges from as low as 53 feet to as much as 146 feet (fig. 6). Alluvium occurs along present stream channels and preglacial drainage ways.

Glacial drift was first deposited in the Reservation about 20,000 years ago by ice lobes that advanced into the area from the northwest. This drift consists mostly of grayish-brown, sandy to stoney till (Wright and others, 1970). Several later stages of glaciation, marked by the advance and retreat of several ice lobes, produced the present-day landscape. The reddish-brown surficial outwash in the Reservation was deposited by glaciers that advanced into the region from the northeast near the end of the Wisconsin glaciation about 10,000 years ago. After the retreat of the last ice lobe, sediments were deposited in the valleys of tributaries to the St. Louis River, and poorly drained organic materials in wetland areas were transformed into peat (Eng, 1979).

Unconfined-drift aquifers are under water-table conditions. Water levels in these aquifers rise in response to precipitation or snowmelt that infiltrates the land surface and percolates to the water table. The water level in a representative well completed in the unconfined-drift aquifer generally increased during months with significant precipitation and dropped during dry periods (fig. 7). Water-level fluctuations in this well were about 2.5 feet during an 8-year period. Ground water in the unconfined-drift aquifers generally moves toward the St. Louis River (fig. 5). Locally, however, the ground water discharges to tributaries of the St. Louis River (fig. 8). 


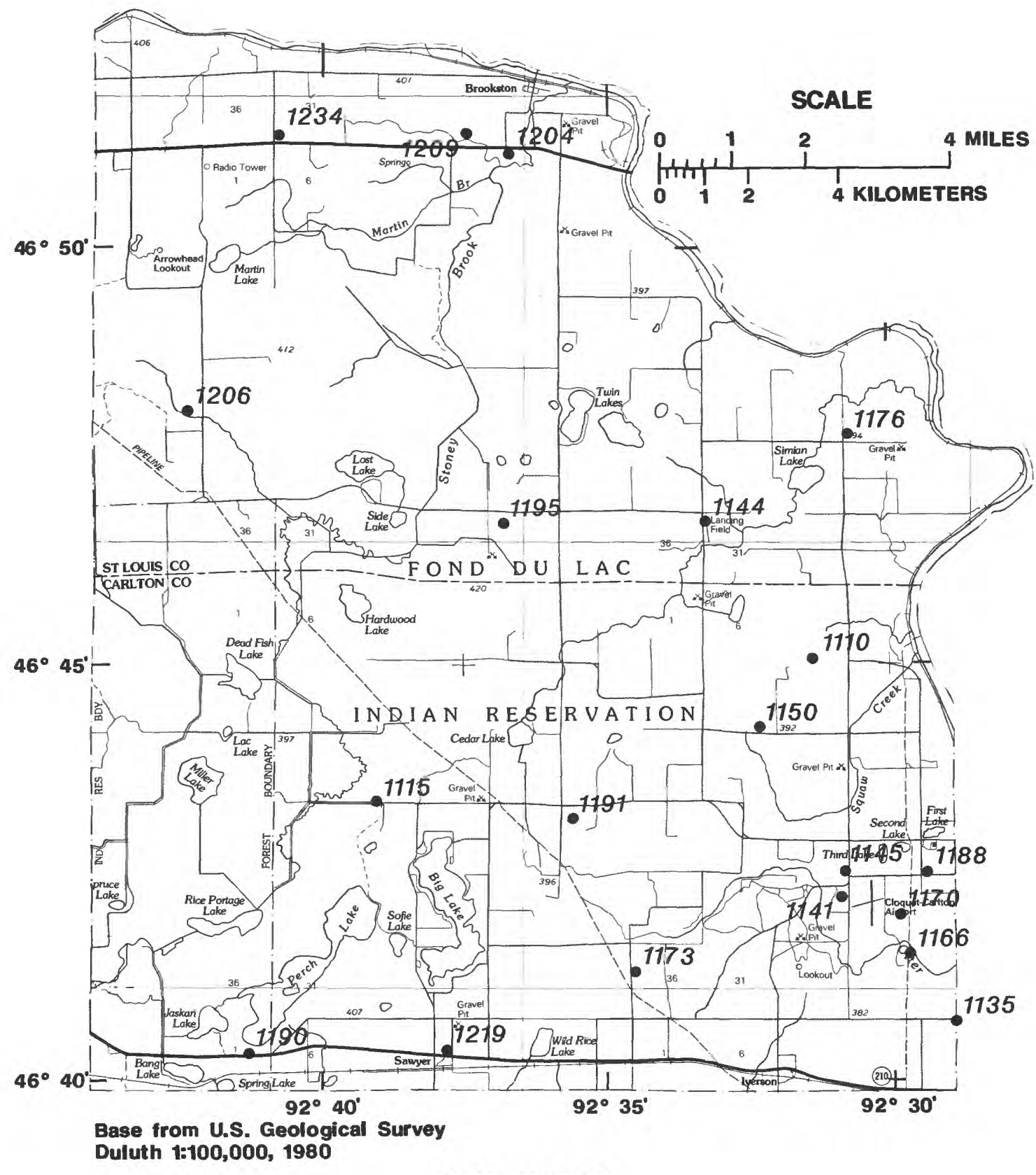

EXPLANATION

1176 Elevation of the top of the Thompson Formation

FIGURE 4.--Elevations of the top of the bedrock in the Fond du Lac Indian Reservation. 


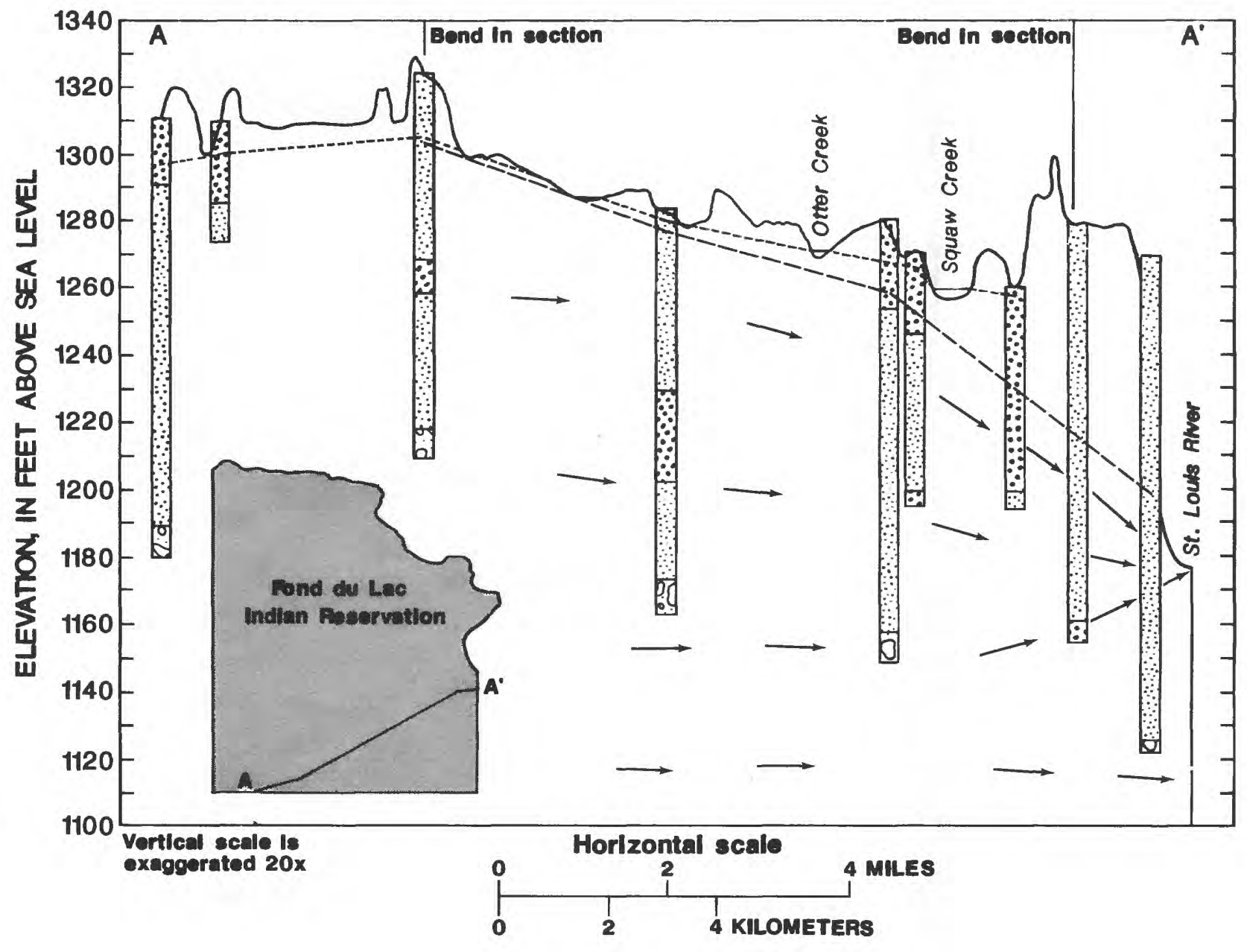

\section{EXPLANATION}

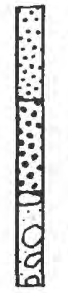

TII

Sand and gravel

Bedrock
Approximate potentiometric surface in bedrock

Approximate water table level in unconsolldated deposits

Direction of ground-water flow

FIGURE 5.--Generallzed hydrogeologic section through the southeastern corner of the Fond du Lac Indlan Reservation. 
The confined-drift aquifers consist of sand and gravel lenses of variable size that occur discontinuously throughout the area rather than as one large, extensive, confined-drift aquifer. These lenses, which range in size from several hundred square feet to tens of square miles, may be hydraulically connected, but they are more likely separated hydraulically by till. The use of confined-drift aquifers as a source of supply varies, depending on the hydraulic properties, areal extent, thickness, accessibility to recharge, and interconnection of the aquifers.

Water in the confined-drift aquifers is under artesian conditions. Water levels in tightly cased wells completed in these aquifers rise above the top of the aquifer in response to hydrostatic pressure. Local rainfall and snowmelt cause the water level to rise much more slowly in the confined-drift aquifers than in the unconfined-drift aquifers because the confining units retard the vertical leakage of water to these aquifers.

\section{Hydraulic Characteristics}

An aquifer commonly is evaluated in terms of saturated thickness, hydraulic conductivity, transmissivity, potential well yield, and storage coefficient. These aquifer properties largely determine the capability of an aquifer to store, transmit, and yield water.

The saturated thickness of an aquifer is indicative of the amount of water potentially available to wells. A saturated thickness of only a few feet generally is sufficient for development of household supplies in the glacial drift aquifers. The saturated thickness of the aquifers in the Reservation varies from 20 feet to 40 feet in the unconfined-drift aquifers and from 5 feet to 20 feet in the confined-drift aquifers.

Withdrawal of water from a well lowers the water level around the well in direct proportion to the rate at which water is withdrawn and the storage coefficient of the aquifer. Aquifers with a large storage coefficient can yield water to a well with less drawdown than aquifers with a low storage coefficient. Generally the storage coefficient of unconfined aquifers is in the range of 0.1 to 0.3 , and the storage coefficient of confined aquifers is in the range of $1 \times 10^{-5}$ to $1 \times 10^{-3}$. Hence, the water level will drop less in the unconfined-drift aquifers than in the confined-drift aquifers in response to a given withdrawal.

Transmissivity is a measure of an aquifer's capacity to transmit water. It is directly proportional to the saturated thickness and the hydraulic conductivity of the aquifer. Although transmissivity does not indicate the long-term capability of an aquifer to yield water, especially under extreme conditions of drought and pumpage, it does provide a basis for assessment of potential yields to wells. 


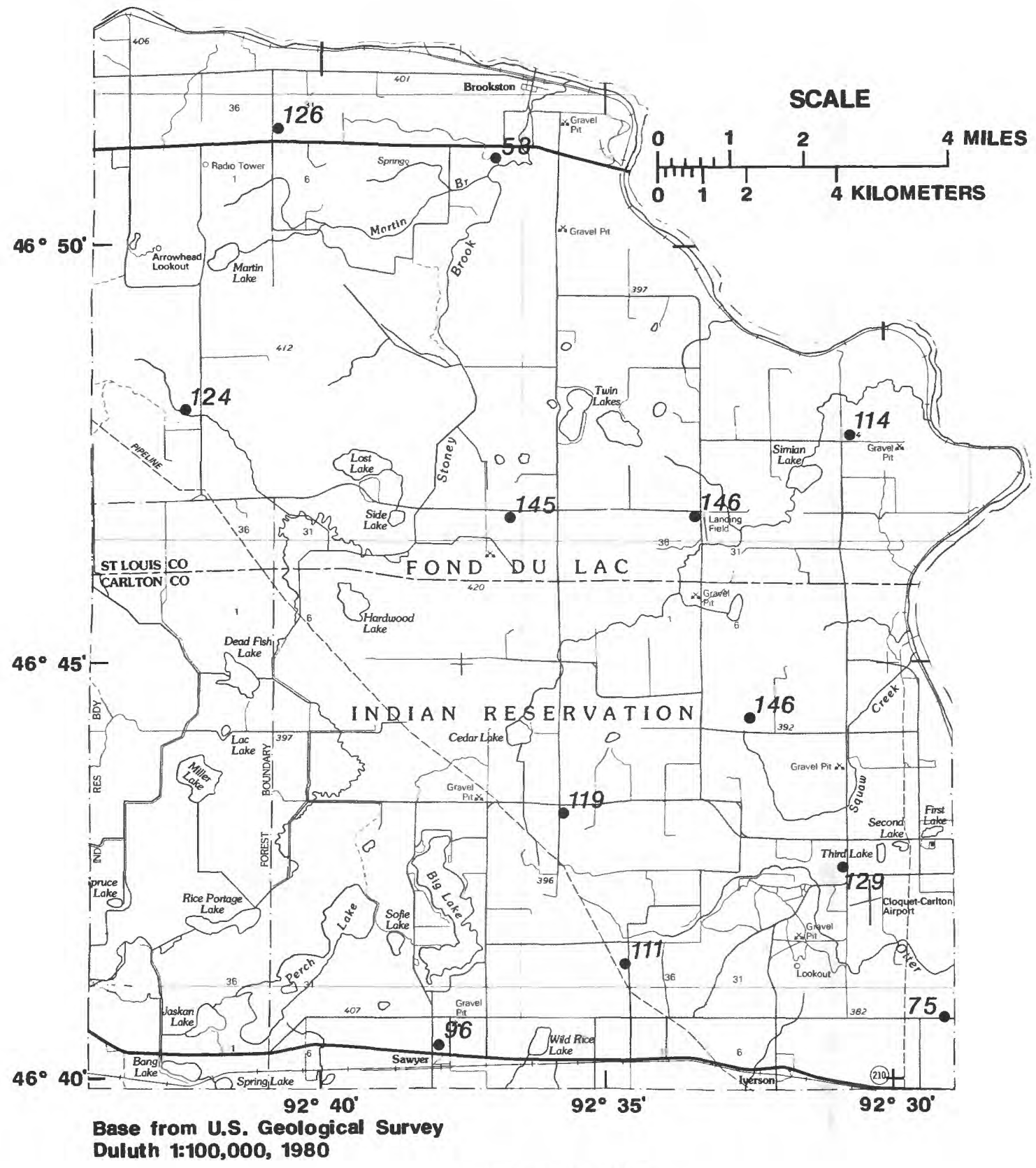

EXPLANATION

129 Thickness of glacial drift

FIGURE 6.--Thicknesses of glacial drift in the Fond du Lac Indian Reservation. 

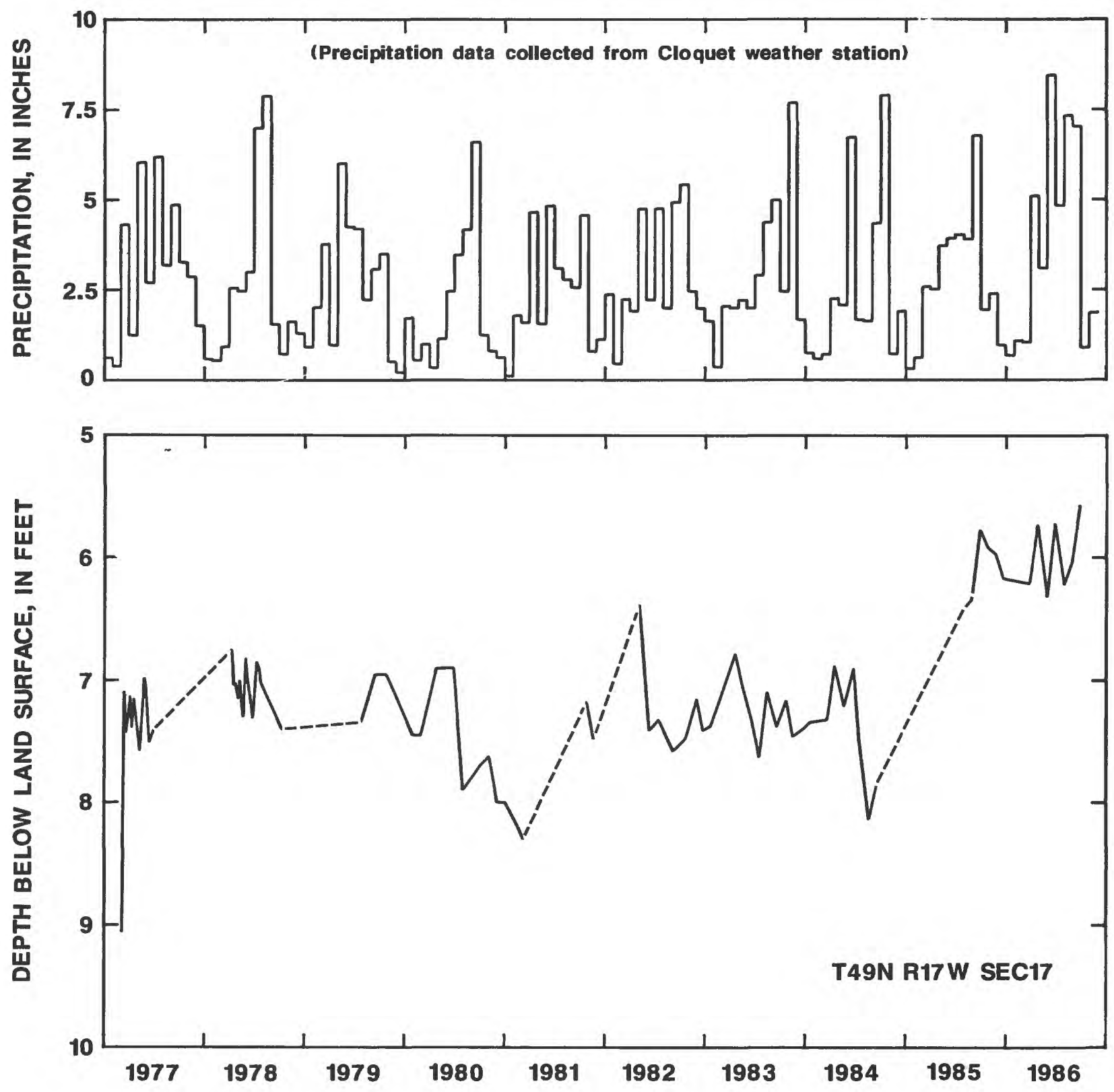

FIGURE 7.--Precipitation and water level in a representative well in the unconfined-drift aquifer in the Fond du Lac Indian Reservation for water years 1977-1986. 


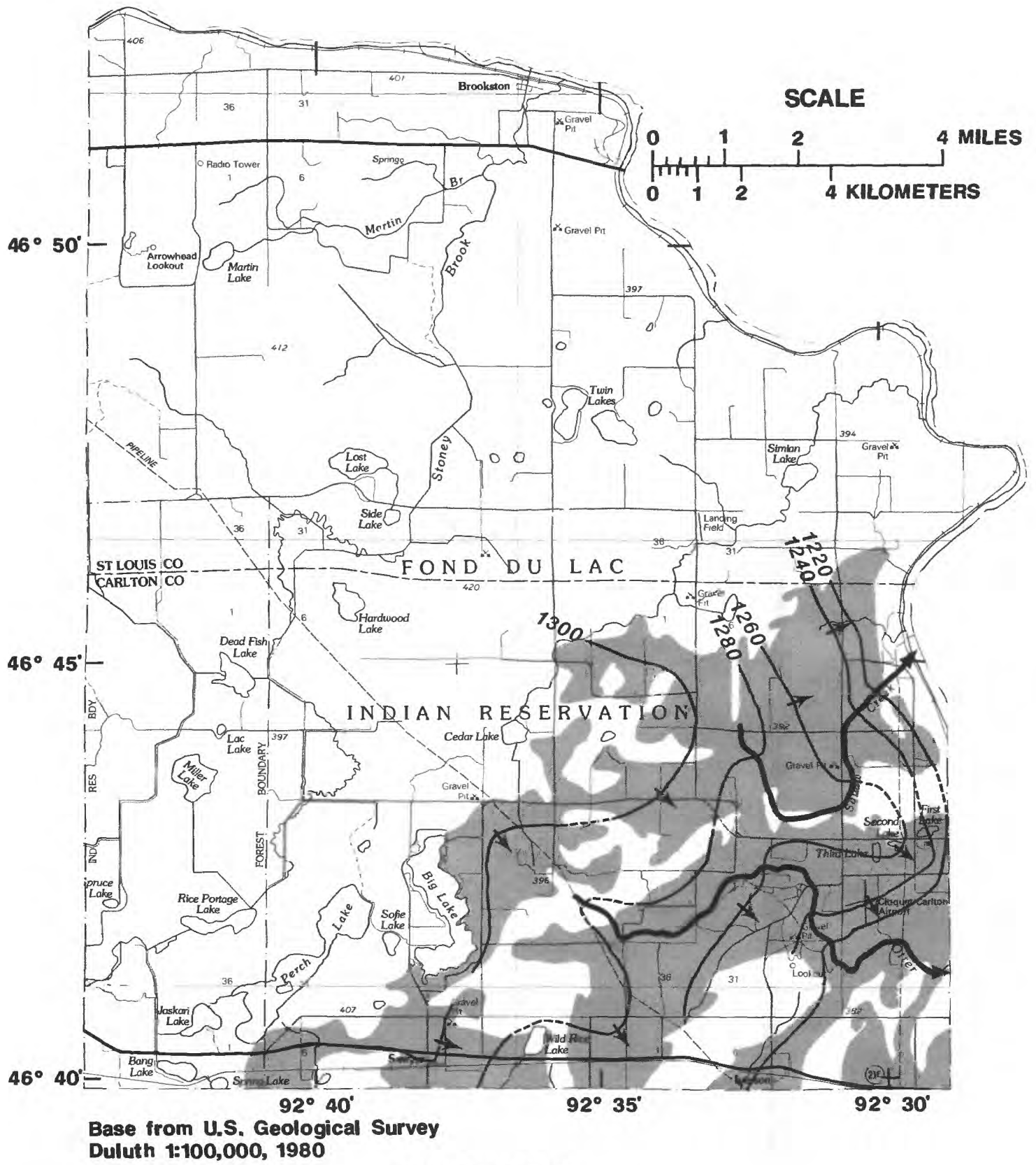

EXPLANATION

Unconfined-drift aquifers

Potentiometric surface contours--shows altitude of water levels in unconfined-drift aquifers. Interval 20 feet. Datum is sea level.

$\rightarrow$ Direction of ground-water flow

$\longrightarrow$ Stream

FIGURE 8.--Potentiometric surface and direction of ground-water flow in unconfined-drift aquifers in the Fond du Lac Indian Reservation in summer 1983. 
Transmissivity of the unconfined-drift aquifers in much of the Reservation was estimated to be less than 5,000 square feet per day ( $\mathrm{ft}^{2} / \mathrm{d}$ ), but in part of the aquifer the transmissivity was estimated to be $20,000 \mathrm{ft}^{2} / \mathrm{d}$ (fig. 9). These estimates were derived from the saturated thickness and hydraulic conductivity of the aquifers as determined from test drilling. Transmissivity of unconfined-drift aquifers throughout Minnesota generally is in the range of 5,000 to $20,000 \mathrm{ft}^{2} / \mathrm{d}$ (Helgesen, 1977; Miller, 1982; and Myette, 1984).

The estimated transmissivity of the confined-drift aquifers is lower than of the unconfined-drift aquifers. The small saturated thickness of the confined-drift aquifers limits the transmissivity of these aquifers. Estimates calculated from the specific capacity of wells ranged from $100 \mathrm{ft}^{2} / \mathrm{d}$ to $2,500 \mathrm{ft}^{2} / \mathrm{d}$ (fig. 10). These estimates are likely to be lower than the actual transmissivity. Akin and Jones (1952) estimated the transmissivity on the basis of an aquifer test to be $4,000 \mathrm{ft}^{2} / \mathrm{d}$. The location of the aquifer test is just outside the Reservation very near the southeastern corner.

The theoretical yield of wells completed in the glacial-drift aquifers is estimated from the transmissivity of the aquifer and the following assumptions: (1) the well is open to the full saturated thickness of the aquifer, is 100 percent efficient, and is 12 inches in diameter; (2) the drawdown after 30 days of pumping is equal to two-thirds of the original saturated thickness or, in the case of confined-drift aquifers, the total available hydraulic head (which is equal to the vertical drop between the static water level and the top of the aquifer); (3) interference from other pumping wells and the effects of hydrologic boundaries are negligible; and (4) the storage coefficient is 0.2 for unconfined aquifers and $2.0 \times 10^{-4}$ for confined aquifers. Using these assumptions, the estimated yield of wells in the unconfined-drift aquifers ranges from about 100 gallons per minute (gal/min) to as much as $1,000 \mathrm{gal} / \mathrm{min}$ ( $\mathrm{fig}$. 11). The estimated yield is directly proportional to the transmissivity shown in figure 9 . The map of potential yields is intended to identify areal differences in aquifer productivity rather than to determine the best locations for wells on a sitespecific basis.

The estimated well yield is lower for confined-drift aquifers than for unconfined-drift aquifers (fig. 12). Values range from about $50 \mathrm{gal} / \mathrm{min}$ along the eastern and northern boundaries of the Reservation to $250 \mathrm{gal} / \mathrm{min}$ near the southwestern part. The small size of many of the sand and gravel lenses that comprise the confined-drift aquifers limits their potential yield to wells.

The yield of wells completed in the bedrock aquifer was estimated by multiplying the specific capacity times the maximum available drawdown. This method of estimation underestimates the yield because the borehole of the well penetrates only a small part of the total thickness of the aquifer.

The estimated yield of 20 bedrock wells along the eastern and northern sides of the study area ranges from 5 to $250 \mathrm{gal} / \mathrm{min}$, except for one well whose estimated yield was $4,000 \mathrm{gal} / \mathrm{min}$. The location of this well is in the northeastern part of the Reservation in section 11 of township 50 north, range 18 west (fig. 12). 


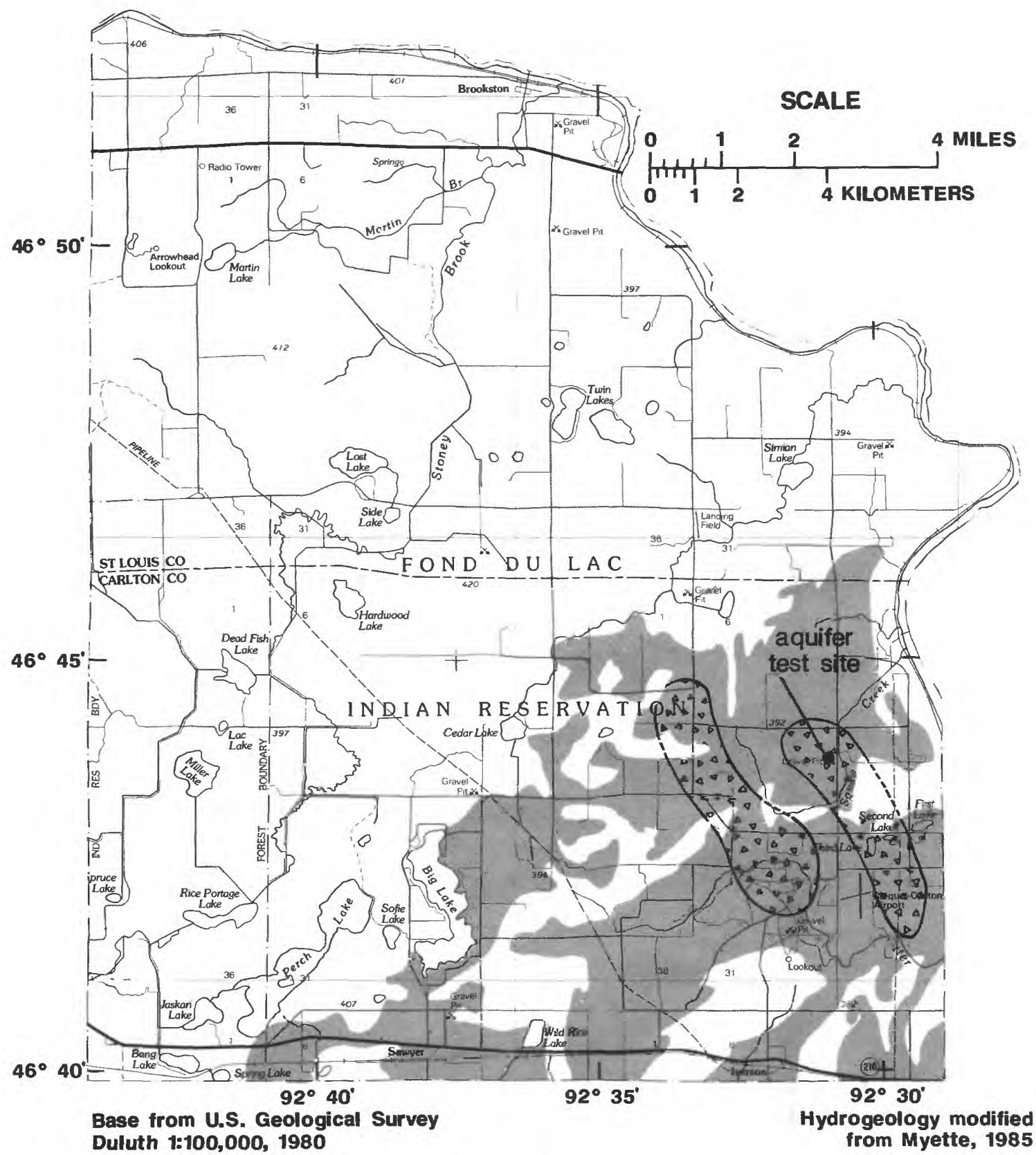

\section{EXPLANATION}

Range in transmissivity, in feet squared per day

$$
\begin{aligned}
& 0 \text { to } 5,000 \\
& \therefore \therefore \square, 000 \text { to } 20,000
\end{aligned}
$$

FIGURE 9.--Transmissivity of unconfined-drift aquifers in the Fond du Lac Indian Reservation. 


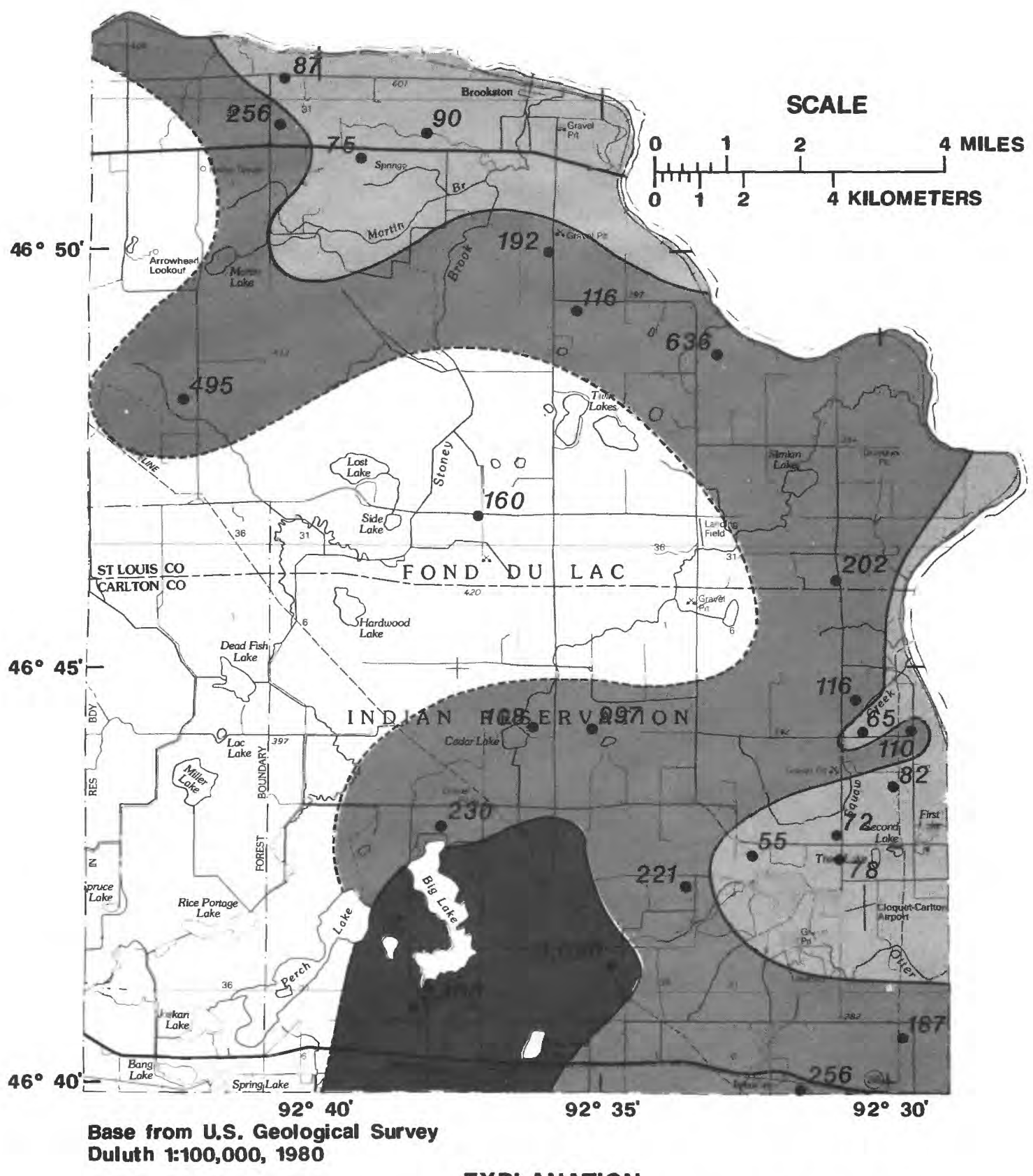

EXPLANATION

Range in transmissivity in feet squared per day

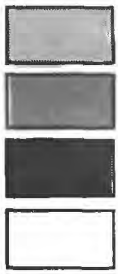

0 to 100

100 to 1,000

1,000 to 2,500

Insufficient data to estimate transmissivity

636 Transmissivity data point

FIGURE 10.--Transmissivity of confined-drift aquifers in the Fond du Lac Indian Reservation. 


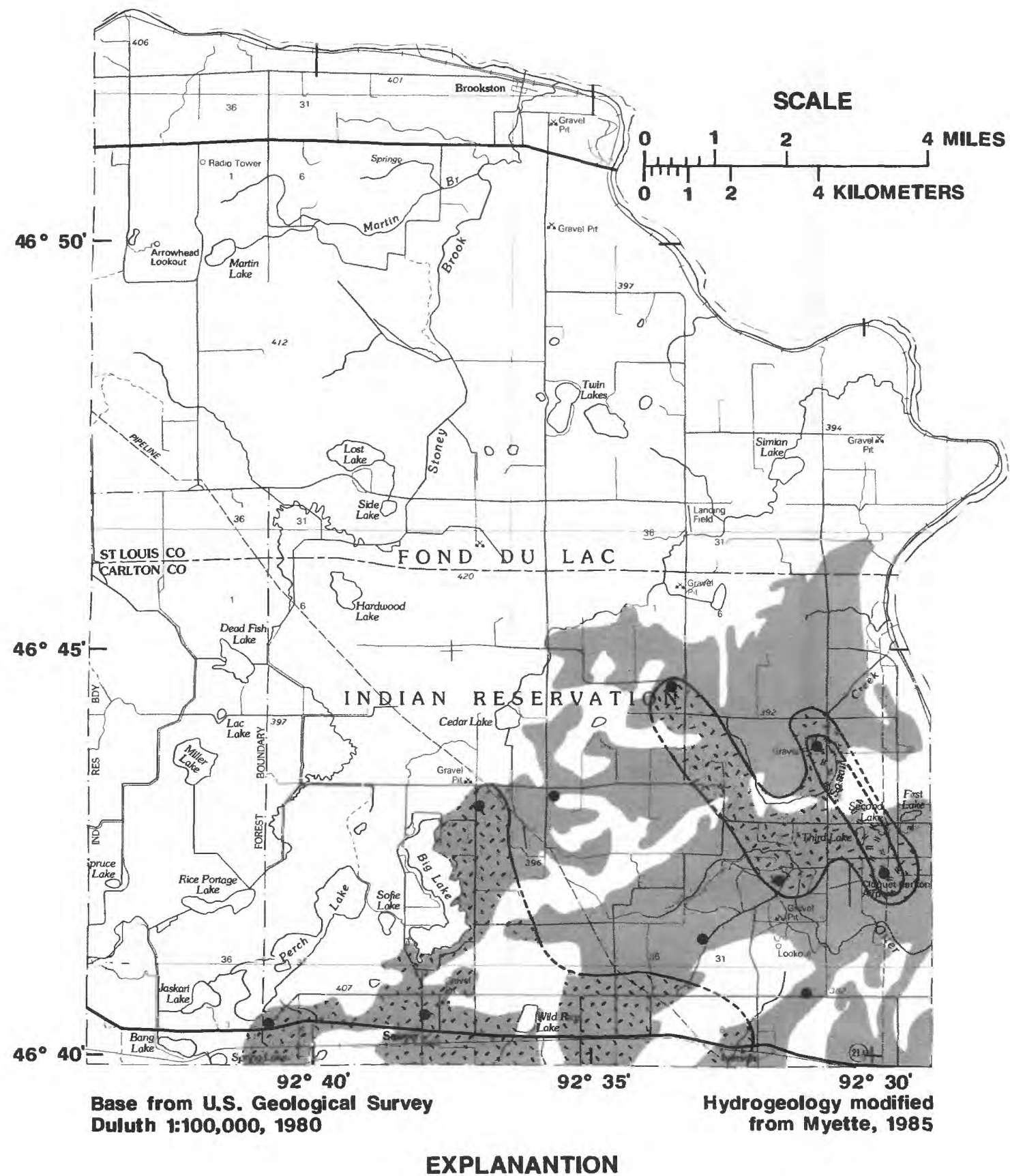

Range in potential yield, in gallons per minute

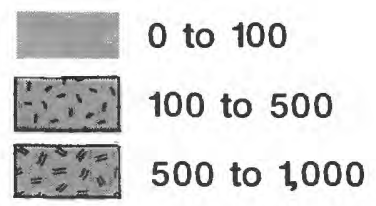

- Potential yield data point

FIGURE 11.--Estimated potential yield to wells completed in unconfined-drift aquifers in the Fond du Lac Indian Reservation. 


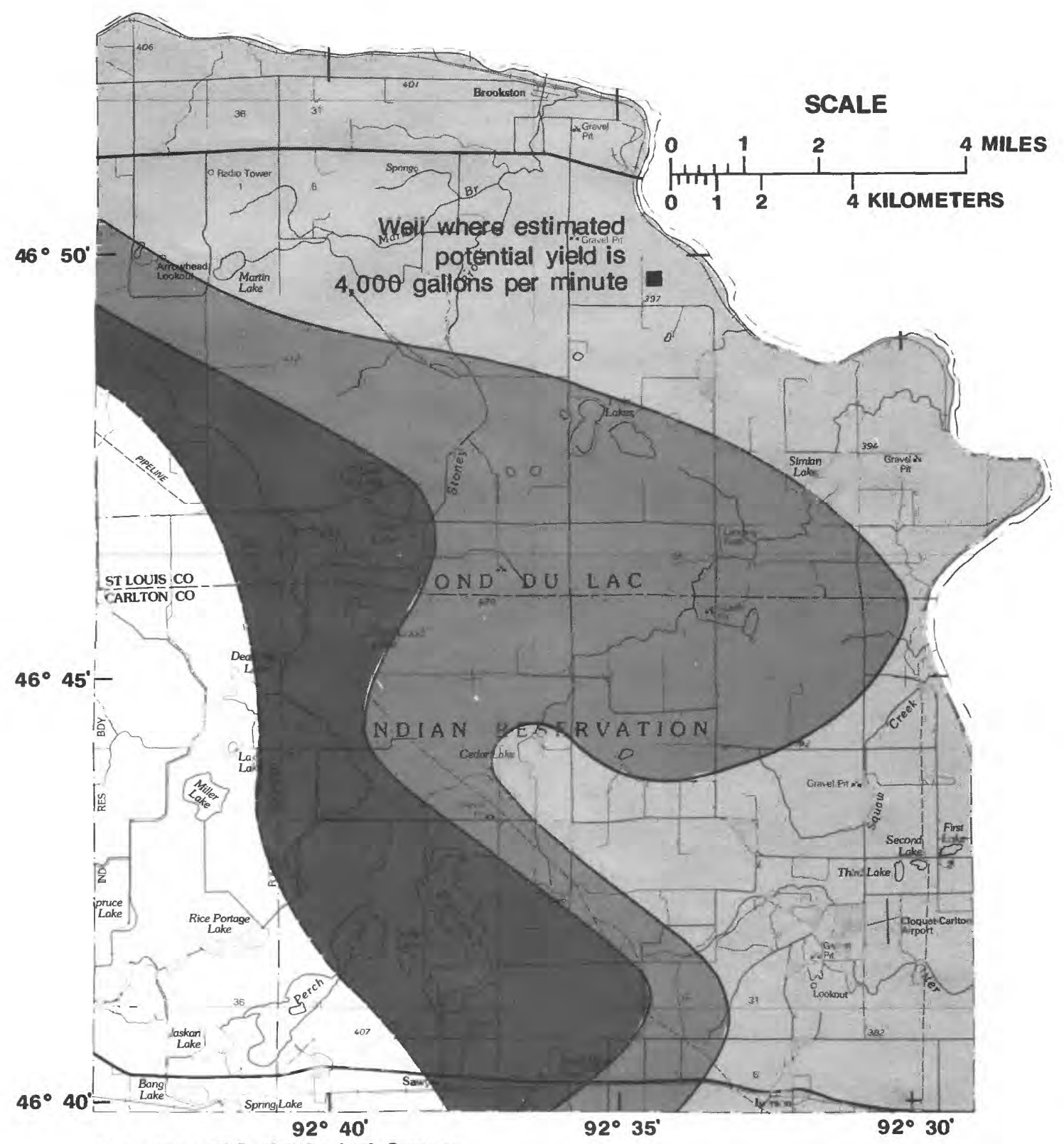

Base from U.S. Geological Survey Duluth 1:100,000, 1980

\section{EXPLANATION}

Range in potential yield, in gallons per minute

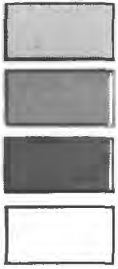

0 to 50

50 to 100

100 to 250

Insufficient data to estimate potential yield

FIGURE 12.--Estimated potential yield to wells completed in the confined-drift aquifers in the Fond du Lac Indian Reservation. 
The yield from a well completed in the bedrock depends on the number and interconnection of fractures intersected by the borehole. The fractures vary in density throughout the aquifer and, as a consequence, well yields vary considerably. Fractures in the bedrock generally increase in density along fault zones and in areas where the bedrock is more highly folded. Drilling is the only means to determine where water-yielding fractures occur in the bedrock.

\section{Surface Water}

\section{Major Surface-Water Features}

Surface-water resources in the Reservation include many lakes, marshes, and wetlands, several streams, and many miles of drainage ditches. The St. Louis River, which is the major stream in the area, forms the northern and northeastern boundary of the Reservation. All the drainage basins in the Reservation are part of the St. Louis River basin, except for a small basin in the south central part of the Reservation that is part of the Kettle River basin ( $f i g .13$ ).

Lakes in the study area have a combined surface area of 3,000 acres. Many of these lakes are shallow and small. One of the larger ones, Big Lake, is extensively developed for homesites along its shoreline and is heavily used for recreation. The level of Big Lake has fluctuated about two feet during the past 10 years.

\section{Streamflow Characteristics}

The discharge hydrographs in figure 14 show variations in flow of the four major streams in the Reservation during the 1984 water year (October 1, 1983 - September 30, 1984). Hydrographs for the three smallest streams, Otter Creek, Simian Creek, and Squaw Creek, assume constant low-flow conditions during the winter months when operation of the gaging station was discontinued. The seasonal pattern of streamflow variation for the 1984 water year is assumed to be normal on the basis of precipitation. Annual precipitation during the 1984 water year measured at the Cloquet weather station was 31 inches, which is equal to the mean annual precipitation for the past 35 years of record (fig. 3).

During the month of October 1983, rain storms of less than an inch caused observable increases in discharge in all four streams (fig. 14). The flow of Stoney Brook, where a year-round gage was installed, responded to rain storms of one to two inches in late November 1983, before receding to base-flow conditions during winter. One noteworthy storm of three inches, which occurred about the end of the first week of November, caused a negligible effect on the flow of Stoney Brook. This storm may have occurred in a small area in the vicinity of the rain gage, which is about five miles east of the Stoney Brook watershed. 


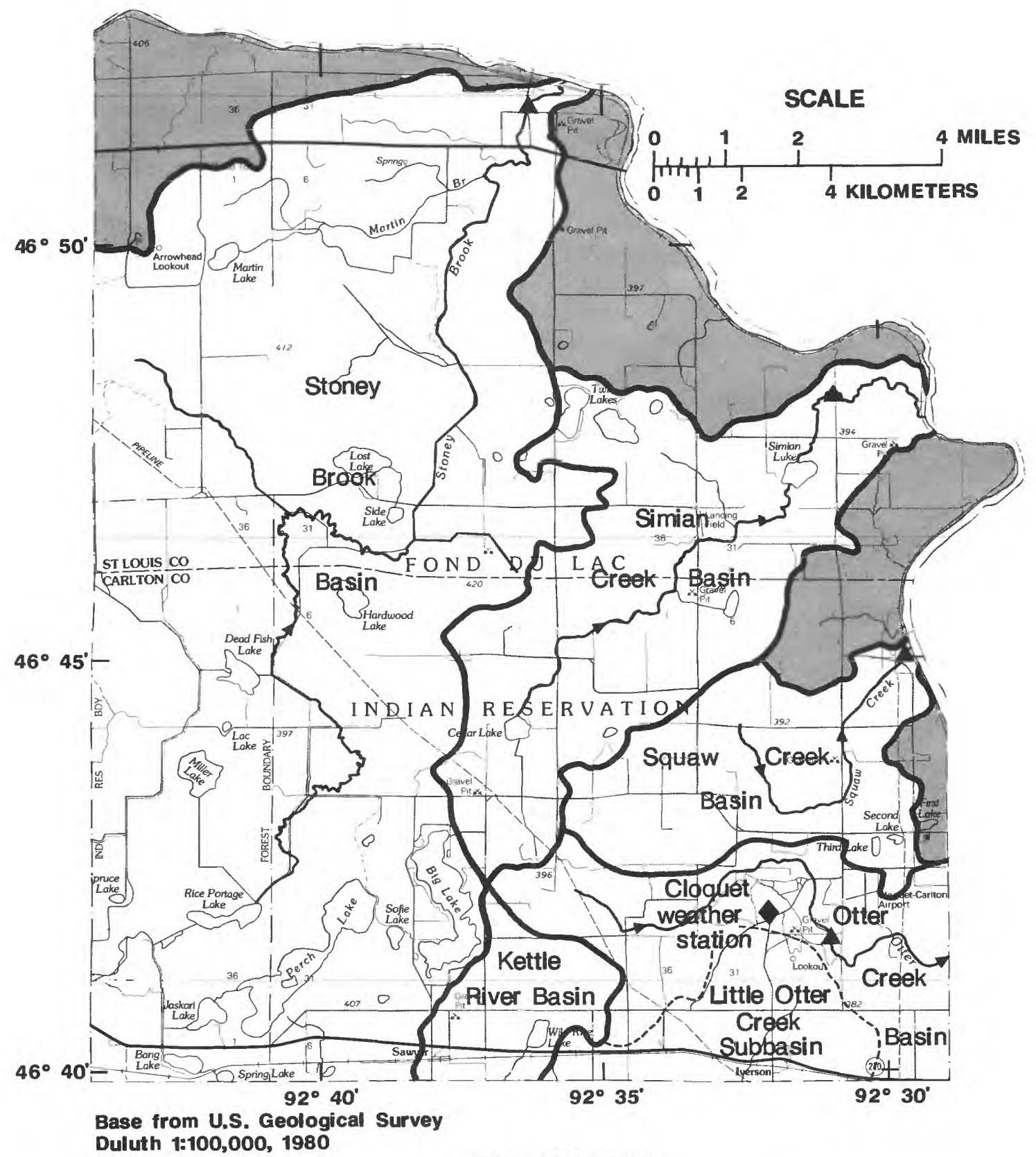

Duluth $1: 100,000,1980$

EXPLANATION

Direct runoff to St. Louis River

- Basin boundary

- Streamflow gaging station

FIGURE 13.--Basin boundaries in the Fond du Lac Indian Reservation. 
Following freeze-up in winter, streamflow gradually receded to base flow until spring, when snowmelt and precipitation initiated high-flow conditions. The hydrographs in figure 14 show two well-defined peaks in each of the four streams during the spring high-flow period. The first peak was after snowmelt in early April, and the second was in mid-June because of precipitation.

Runoff in Stoney Brook quickly receded after the highest peak in June, but rose sharply again in response to precipitation in late June. The increase in streamflow indicates that soil moisture was at or close to capacity in the Stoney Brook watershed just before the storm in late June. Streamflow in Simian Creek also responded to the late June storm, but in a more subdued manner than in Stoney Brook. Precipitation from the late June storm caused very little response in the flow of Squaw Creek and Otter Creek (fig. 14). Soil moisture in these smaller basins probably was depleted so that all, or nearly all, the precipitation from the late June storm was retained.

The hydrographs show that streamflow gradually decreased during summer, when low-flow conditions commonly occur. Precipitation tends to be retained in the soil and evapotranspired during this period. The hydrographs in figure 14 show that minor storms in August and September produced very little runoff.

\section{Unit Runoff and Basin Characteristics}

The average discharge of streams, expressed in cubic feet per second $\left(\mathrm{ft}^{3} / \mathrm{s}\right)$, is somewhat proportional to basin size (fig. 14). Average discharge increases with basin size because of increased availability of water from precipitation. Average discharge of Stoney Brook was $82 \mathrm{ft}^{3} / \mathrm{s}$. Average discharge from the three smaller streams ranged from 9 to $20 \mathrm{ft}^{3} / \mathrm{s}$ (fig. 14).

Unit runoff, expressed in inches, is the depth of the yearly volume of runoff from a basin if spread evenly across the area of the basin. Unit runoff reflects the amount of runoff generated per unit area. Simian Creek basin produced the most inches of unit runoff (17.3 in) during the 1984 water year, and Stoney Brook produced the second largest amount (14.4 in) (fig. 14). The large size of Stoney Brook basin, and the presence of drainage ditches, probably account for the high rate of runoff in this basin. Otter Creek, which produced the least amount of runoff, flows through surficial outwash that stores precipitation and snowmelt. The outwash is potentially capable of transmitting significant quantities of water to the stream during dry, lowflow periods.

\section{Water Quality}

\section{Water Types}

Figure 15 shows the chemical composition of individual water samples collected from wells, streams, and a lake in the Reservation. Each point on the diagram defines the proportion of major cations and anions in the sample as a percentage of the total cations and anions. 

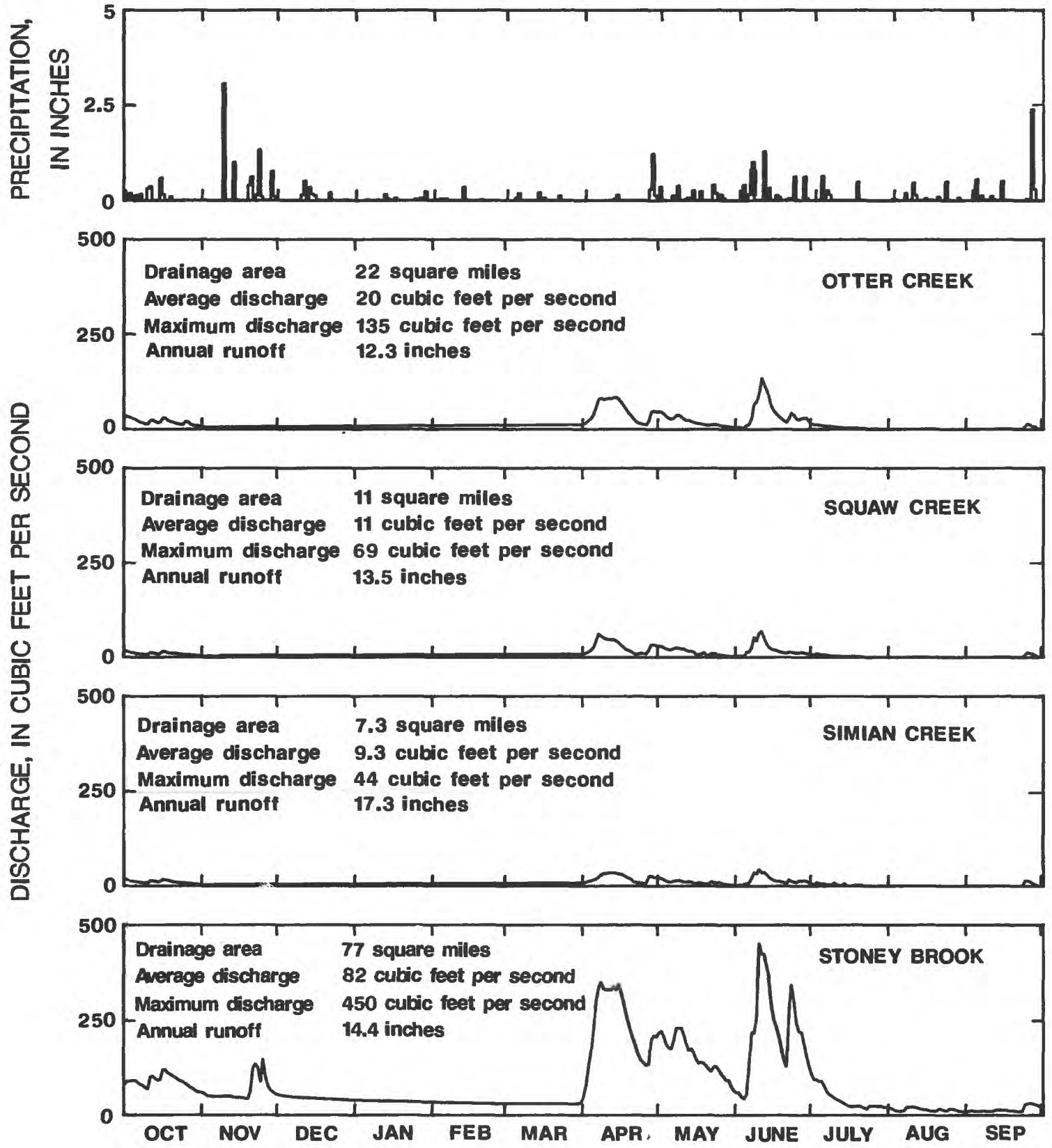

FIGURE 14.--Precipitation and discharge of four streams in the Fond du Lac Indian Reservation for the 1984 water year. 


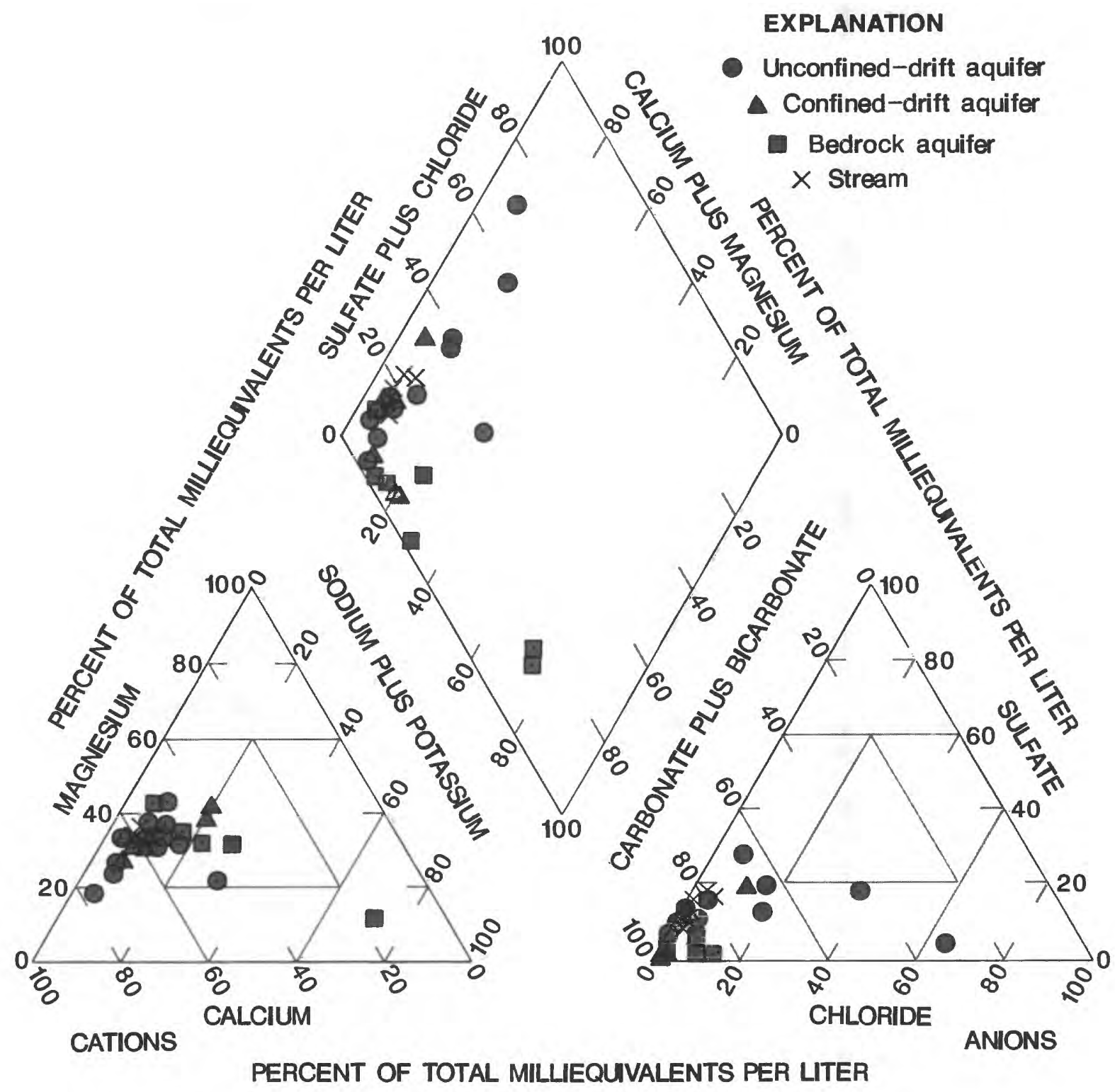

FIGURE 15.--Percent of total cation and anion concentrations in groundand surface-water samples collected in the Fond du Lac Indian Reservation. 
Calcium and magnesium are the dominant cations and bicarbonate is the dominant anion in all but two of the samples. The two outlying points in the diagram represent samples from an unconfined-drift well where chloride is the dominant anion, and from a bedrock well where sodium is the dominant cation. The diagram indicates that ground water and surface water in the study area are of similar composition. The diagram also suggests some subtle differences in the quality of water from the three aquifers. Water samples from the unconfined-drift aquifers generally contain a greater proportion of chloride and sulfate anions and calcium and magnesium cations than water samples from the bedrock aquifer.

The greater proportion of chloride in samples from the unconfined-drift aquifers, particularly the sample where chloride is the dominant anion, may be due to contamination by road salts. Another possible source is fertilizer, although it is less likely because of the limited amount of land used for agriculture in the Reservation. Sulfate concentrations may be lower in samples from the confined-drift aquifers than in samples from the unconfineddrift aquifers due to reduction of sulfate ions. This reaction commonly occurs biochemically under reducing conditions.

The higher proportions of calcium and magnesium cations in samples from the unconfined-drift aquifers than in samples from the bedrock aquifer probably are due to an increased abundance of soluble minerals in the unconfined-drift aquifers. Calcium- and magnesium-carbonate minerals may have been mixed into the surficial outwash by successive advances and recessions of the glaciers. These minerals react with carbonic acid, which is formed when atmospheric carbon dioxide dissolves in the ground water, and release calcium and magnesium ions in the process.

The higher proportion of sodium cations in samples from bedrock wells, particularly the one where sodium is the dominant cation, is typical of samples from many wells in northeastern Minnesota. High concentrations of sodium occur locally in the crystalline bedrock aquifers of northeastern Minnesota, particularly along the north shore of Lake Superior (Anderson, 1986). The sodium concentration in water from the bedrock aquifer depends in part on the mineralogic composition of the rocks. Feldspar minerals are common sources of sodium in crystalline rocks (Hem, 1985).

Lower concentrations of sulfate and chloride in samples collected from wells in the bedrock-aquifer of the Reservation fit the overall pattern for the area. Both ions are present at low concentrations in crystalline bedrock aquifers in much of eastern and northeastern Minnesota (Anderson, 1986). Both ions, however, occur locally in high concentrations outside the study area, particularly in the volcanic rocks along the north shore of Lake Superior.

The stiff diagrams in figures 16 and 17 schematically represent the ionic composition of individual samples collected from ground- and surface-water sites. The total amount of cations represented on the left side of each diagram is balanced within 10 percent by the total amount of anions represented on the right side. The width of each diagram is directly proportional to the dissolved solids content of the sample. The diagrams show 


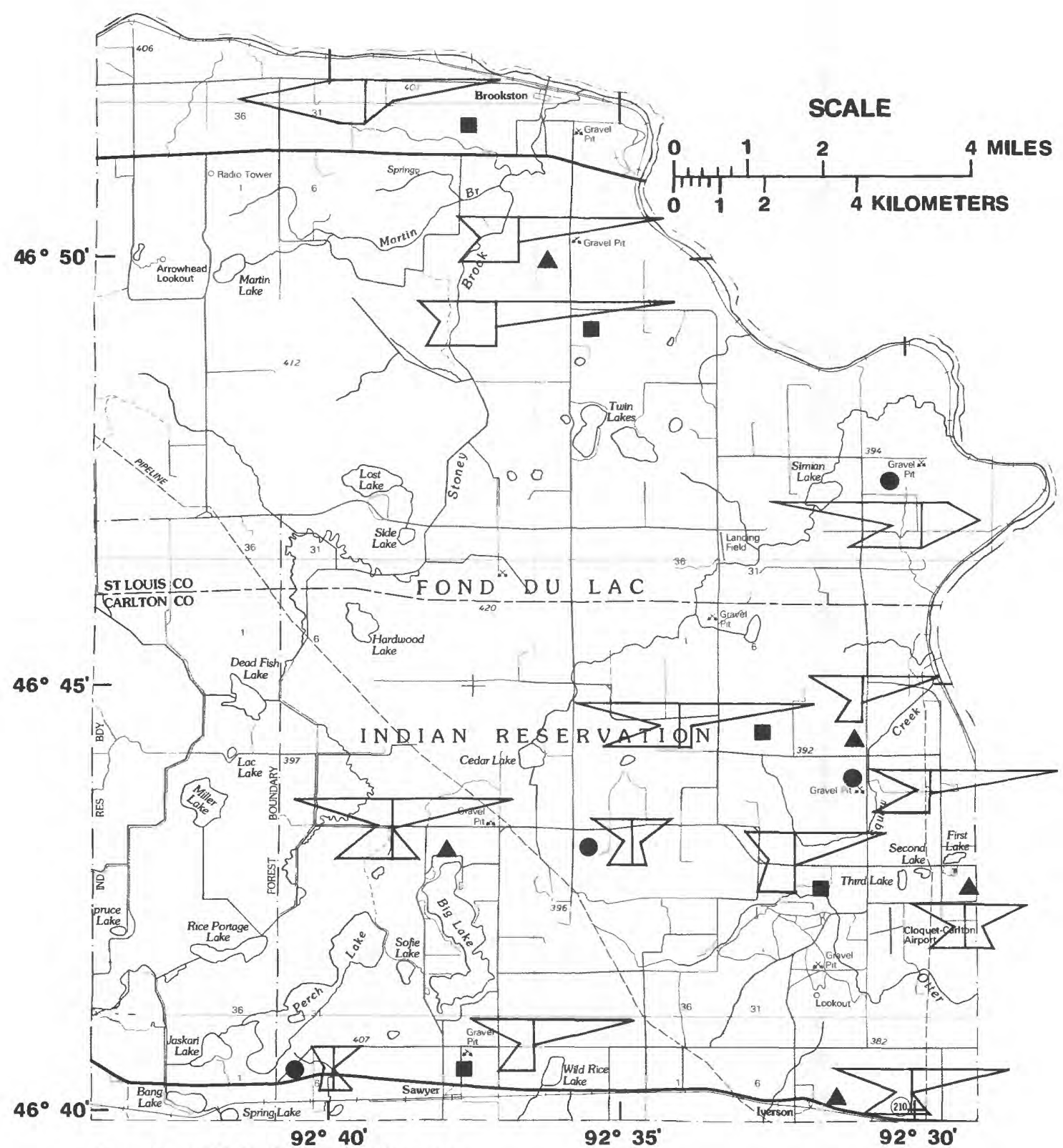

Base from U.S. Geological Survey Duluth 1:100,000, 1980

EXPLANATION

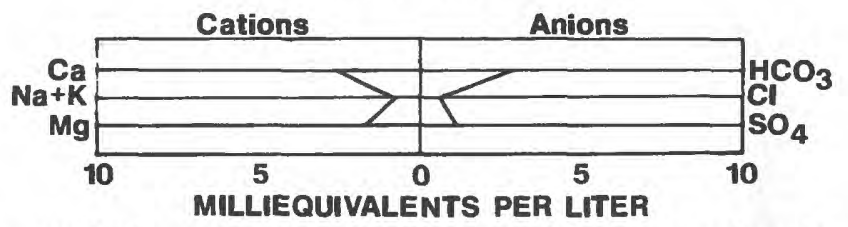

Water analysis pattern--shows concentrations of major ions expressed as milliequivalents per liter

- Well in unconfined-drift aquifer

$\Delta$ Well in confined-drift aquifer

- Well in bedrock aquifer

FIGURE 16.--Ion balances of selected samples collected from wells completed in the unconfined-drift, confined-drift, and bedrock aquifers in the Fond du Lac Indlan Reservation. 


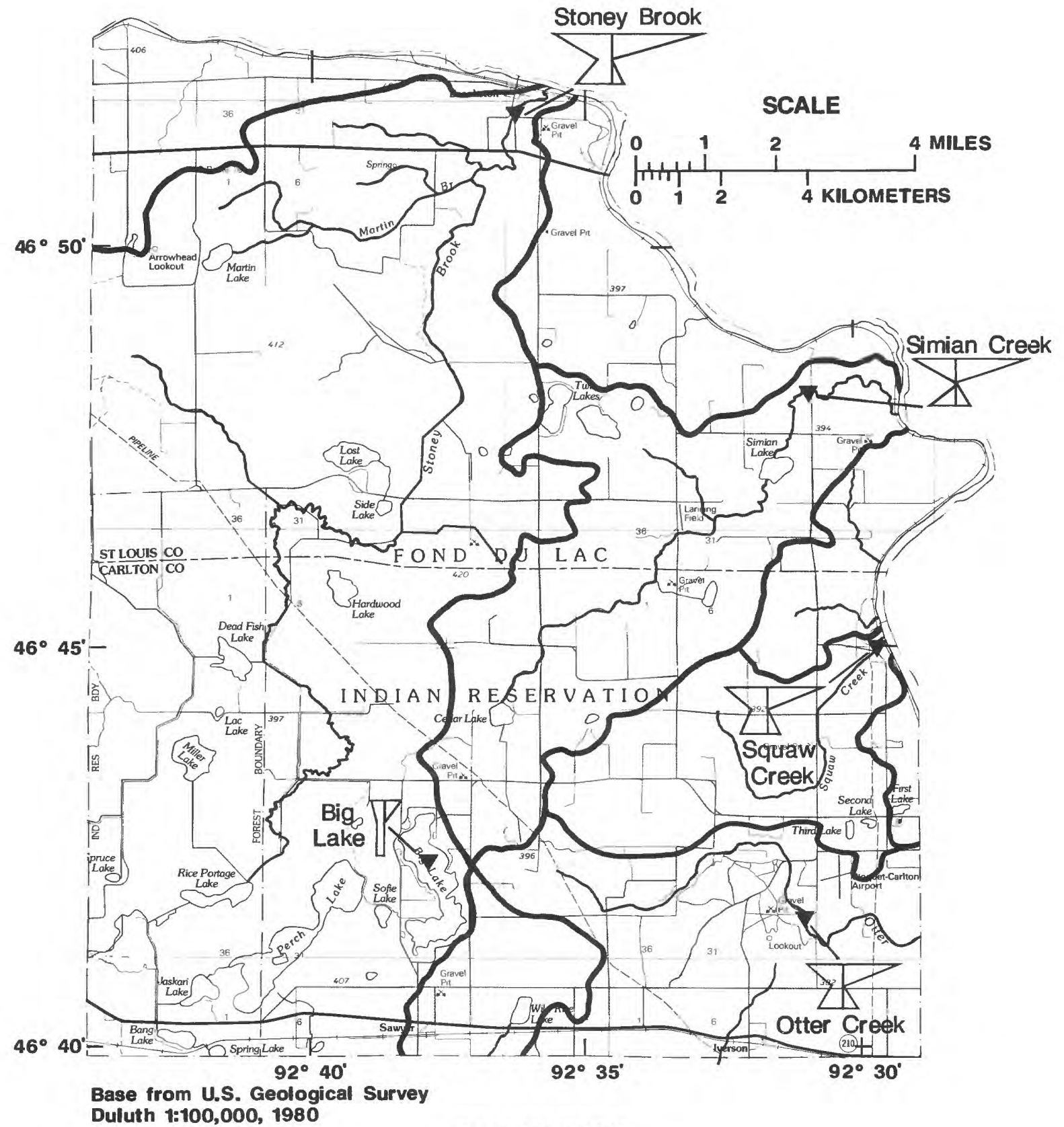

Duluth 1:100,000, 1980

EXPLANATION

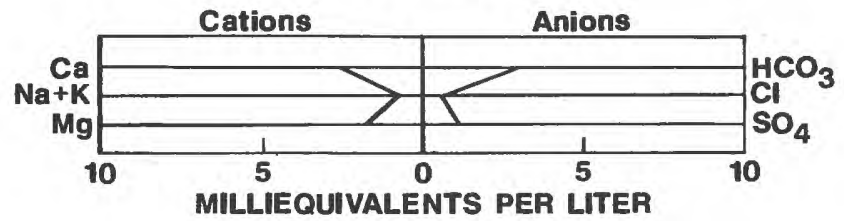

Water analysis pattern--shows concentrations of major ions expressed as milliequivalents per liter

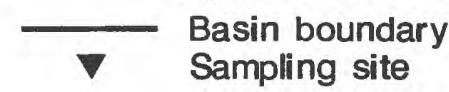

FIGURE 17.--Ion balance of selected samples collected from Big Lake and four streams in the Fond du Lac Indian Reservation. 
that calcium and magnesium are the dominant cations and that bicarbonate is the dominant anion in all but two of the samples, which are the ones represented as outliers in figure 15. The surficial-outwash well yielding water that has a high chloride concentration is in the northeastern part of the study area, and the bedrock well yielding water that has a high sodium concentration is in the northern part of the study area (fig. 16).

\section{Quality of Surface Water for Aquatic Life and Recreation}

The quality of water in the lakes and streams in the Reservation appears to be suitable for aquatic life. The concentration of major ions, trace metals, nutrients, dissolved oxygen, and other properties are within the recommended limits proposed by the U.S. Environmental Protection Agency (USEPA) for aquatic habitat (U.S. Environmental Protection Agency, 1986). Most of the surface water can be classified as a calcium magnesium bicarbonate type (fig. 17).

The $\mathrm{pH}$ (a measure of the relative acidity of water) of water samples from both Big Lake and the four principal streams in the Reservation is suitable for aquatic habitat. The $\mathrm{pH}$ values are all in the range of 7.0 to 7.4 (table 1). A $\mathrm{pH}$ value in the range of 6.5 to 9.0 generally is harmless to fish, although the the toxicity of some compounds may be affected in this range (U.S. Environmental Protection Agency, 1986). Values of pH outside the recommended range in surface water can adversely affect the water quality. Some compounds may become more toxic, and some environmentally harmful metals attached to or contained in bottom sediments of lakes and suspended materials in streams may become more soluble (U.S. Environmental Protection Agency, 1986).

Bacteria that indicate contamination from animal wastes are present in all four of the principal streams. Concentrations ranged from 10 to 100 colonies per 100 milliliters (mL) for fecal coliform, and from 160 to 640 colonies per $100 \mathrm{~mL}$ for fecal Streptococci. The USEPA recommends the concentration of fecal coliform in natural waters be within a limit of 2,000 colonies per $100 \mathrm{~mL}$, which is well above the values observed for the streams in the study area. The source of these bacteria are most likely livestock and other animals.

\section{Quality of Ground Water for Household Supply}

Table 2 summarizes water-quality data for samples collected from the three aquifers in the study area. The data indicate that water in the three aquifers is similar. The dissolved-solids concentration and specific conductance, which is proportional to the dissolved-solids concentration in most natural water, are highest in the bedrock aquifer and lowest in the unconfined-drift aquifers. The dissolved-solids content and specific conductance of ground water tend to increase with depth below land surface because of increased time for dissolution of minerals from aquifer materials. 
Table 1.--Summary of water-quality data for samples collected from Big Lake and four streams in the Fond du Lac Indian Reservation

[Values in milligrams per liter except as indicated. $\mathrm{N}$, number of samples; $\mu \mathrm{S} / \mathrm{cm}$, microsiemens per centimeter at $25^{\circ}$ Celsius; *, indicates no analysis]

\begin{tabular}{|c|c|c|c|c|c|c|}
\hline \multirow{2}{*}{$\begin{array}{l}\text { Property or } \\
\text { Constituent }\end{array}$} & \multicolumn{2}{|c|}{ Big Lake } & \multicolumn{4}{|c|}{ Streams ${ }^{1}$} \\
\hline & $\mathrm{N}$ & Value & $\mathrm{N}$ & Rang & & Median \\
\hline $\begin{array}{l}\text { Specific conductance, } \\
\mu \mathrm{S} / \mathrm{cm} \text { at } 25 \text { degrees } \mathrm{C}\end{array}$ & 1 & 35 & 4 & 122 & -174 & 135 \\
\hline $\mathrm{pH}$ & 1 & 7. & 4 & 7.1 & -7.4 & 7.3 \\
\hline Oxygen, dissolved, (0) & 1 & 7.9 & 4 & 5.7 & -8.2 & 6.8 \\
\hline $\begin{array}{l}\text { Coliform, fecal, } \\
\text { (colonies } / 100 \mathrm{~mL} \text { ) }\end{array}$ & * & * & 4 & 20 & -82 & 30 \\
\hline $\begin{array}{l}\text { Streptococci, fecal, } \\
\text { (colonies } / 100 \mathrm{~mL} \text { ) }\end{array}$ & * & * & 4 & 180 & -640 & 305 \\
\hline Calcium, dissolved, (Ca) & 1 & 4.1 & 4 & 18 & -26 & 20 \\
\hline Magnesium, dissolved, ( $\mathrm{Mg}$ ) & 1 & 1.4 & 4 & 5.7 & -9.2 & 6.2 \\
\hline Sodium, dissolved, (Na) & 1 & 1.5 & 4 & 2.5 & -3.4 & 3.0 \\
\hline Alkalinity & 1 & 14 & 4 & 64 & -95 & 69 \\
\hline Sulfate, dissolved, (SO4) & 1 & 3.1 & 4 & 11 & -16 & 13 \\
\hline Chloride, dissolved, (Cl) & 1 & 1.8 & 4 & 1.7 & 4 & 2.4 \\
\hline Silica, dissolved, as $\mathrm{SiO} 2$ & 1 & .2 & 4 & 6.8 & -18 & 13.5 \\
\hline $\begin{array}{l}\text { Solids, dissolved, } \\
\text { as residue on evaporation } \\
\text { at } 105 \text { degrees centigrade }\end{array}$ & * & $*$ & 4 & 8 & -18 & 13.5 \\
\hline $\begin{array}{l}\text { Nitrite plus nitrate, } \\
\text { dissolved, as } \mathrm{N}\end{array}$ & 1 & .01 & * & & * & * \\
\hline
\end{tabular}


Table 1.--Summary of water-quality data for samples collected from Big Lake and four streams in the Fond du Lac Indian Reservation--Continued

Property or Constituent
Ammonia, total, as $\mathrm{N}$

Ammonia + organic $\mathrm{N}$, total, as $\mathrm{N}$

Ammonia + organic $\mathrm{N}$, dissolved, as $\mathrm{N}$

Phosphorus, total, (P)

Phosphorus, total, (P04)

Phosphorus, dissolved, (P)

Organic carbon, dissolved, as $\mathrm{C}$

Organic carbon, suspended, as $\mathrm{C}$
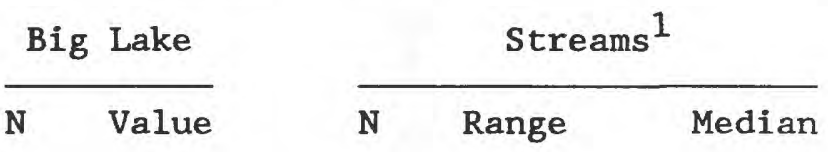

4

$0.03-0.10$

0.04

$$
1
$$

.5

4

$.8-1.2$

1.3

4

$.6-1.0$

.8

1

.05

$4.06-.09$

1

.15

$4 \quad .18-.28$

$1<.01$

$4.04-.07$

* $\quad$ *

$423-33$

31

* $\quad$ *

4

$.5-1.6$

85

1 Streams are Stoney Brook, Otter Creek, Simian Creek, and Squaw Creek. The instantaneous streamflows of these streams at the time of sampling were $80,23,4.2$, and 20 feet $3 / s$, respectively. 
Table 2.--Summary of water-quality data for samples collected from the three principal aquifers in the Fond du Lac Indian Reservation

[Values in milligrams per liter except as indicated. N, number of samples; NA, not applicable; $\mu \mathrm{S} / \mathrm{cm}$, microsiemens per centimeter; $\mu \mathrm{g} / \mathrm{L}$, micrograms per liter; *, indicates no analysis]

\begin{tabular}{|c|c|c|c|c|c|c|c|c|c|}
\hline \multirow{2}{*}{$\begin{array}{l}\text { Property or } \\
\text { constituent }\end{array}$} & \multicolumn{3}{|c|}{ Unconfined-Drift Aquifers } & \multicolumn{3}{|c|}{ Confined-Drift Aquifers } & \multicolumn{3}{|c|}{ Bedrock Aquifer } \\
\hline & $\mathbf{N}$ & Range & Median & $\mathbf{N}$ & Range & Median & N & Range & Median \\
\hline
\end{tabular}

Specific

conductance,

$\mu \mathrm{S} / \mathrm{cm}$ at 25

degrees $\mathrm{C}$

$1285-675$

255

$4220-310$

287

$3240-365$

310

$\mathrm{pH}$

$12 \quad 6.1-7.9$

7.7

10

$6.5-9.0$

7.7

$67.6-8.2$

7.7

Hardness, as $\mathrm{CaCO} 3$

$13 \quad 38-250$

75

$984-170$

120

$654-200$

104

Calcium, dissolved,

(Ca)

21

$9 \quad 23-45$

27

$6 \quad 13-44$

26

Magnesium, dissolved,

(Mg)

Sodium, dissolved, (Na)

Alkalinity, as $\mathrm{CaCO} 3$

Sulfate, dissolved, (SO4) $13.9-16$

$11 \quad 9 \quad .4-23$

2.1

$6.8-11$ 7

Chloride, dissolved, (C1) $13 \quad .5-41$ 2.4 
Table 2.--Summary of water-quality data for samples collected from the three principal aquifers in the Fond du Lac Indian Reservation Continued

\begin{tabular}{|c|c|c|c|c|c|c|c|c|c|c|c|c|}
\hline \multirow{2}{*}{$\begin{array}{l}\text { Property or } \\
\text { constituent }\end{array}$} & \multicolumn{4}{|c|}{ Unconfined-Drift Aquifers } & \multicolumn{4}{|c|}{ Confined-Drift Aquifers } & \multicolumn{4}{|c|}{ Bedrock Aquifer } \\
\hline & $\mathbf{N}$ & Rang & gige & Median & $\mathbf{N}$ & Rang & & Median & $\mathbf{N}$ & Ran & nge & Median \\
\hline $\begin{array}{l}\text { Silica, } \\
\text { dissolved, } \\
\text { as } \mathrm{SiO2}\end{array}$ & 13 & $15-$ & -32 & 19 & 9 & $9.2-$ & 21 & 16 & 6 & $8.1-$ & -17 & 14 \\
\hline $\begin{array}{l}\text { Nitrite + } \\
\text { nitrate, } \\
\text { dissolved, } \\
\text { as } N\end{array}$ & 12 & $.06-$ & 26 & .1 & 6 & $.1-$ & 2.5 & .1 & 4 & $.1-$ & -.1 & .1 \\
\hline $\begin{array}{l}\text { Solids, } \\
\text { dissolved, } \\
\text { as residue on } \\
\text { evaporation at } \\
180 \text { degrees C }\end{array}$ & 13 & $75-$ & -102 & 125 & 9 & $107-$ & 243 & 192 & 6 & $130-$ & -270 & 201 \\
\hline $\begin{array}{l}\text { Arsenic, } \\
\text { total, (As), } \\
\mu \mathrm{B} / \mathrm{L}\end{array}$ & 4 & $1-$ & 3 & 2 & 8 & $1-$ & 6 & 3 & 6 & $1-$ & -49 & 4 \\
\hline $\begin{array}{l}\text { Boron, } \\
\text { dissolved, (B) } \\
\mu \mathrm{g} / \mathrm{L}\end{array}$ & 9 & $10-$ & -30 & 10 & 1 & $\mathbf{N}$ & & 60 & * & * & * & * \\
\hline $\begin{array}{l}\text { Cadmium, } \\
\text { total, (Cd), } \\
\mu \mathrm{g} / \mathrm{L}\end{array}$ & 4 & $1-$ & 9 & 2 & 6 & $1-$ & 1 & 1 & 5 & $1-$ & 1 & 1 \\
\hline $\begin{array}{l}\text { Chromium, } \\
\text { total, (Cr), } \\
\mu \mathrm{B} / \mathrm{L}\end{array}$ & 4 & $10-$ & -20 & 20 & 8 & $10-$ & 20 & 10 & 6 & $10-$ & $-\quad 20$ & 15 \\
\hline $\begin{array}{l}\text { Copper, } \\
\text { total, (Cu), } \\
\mu \mathrm{g} / \mathrm{L}\end{array}$ & 4 & $6-$ & $-\quad 27$ & 10 & 8 & $3-$ & 14 & 5 & 6 & $3-$ & $-\quad 32$ & 7 \\
\hline
\end{tabular}


Table 2.--Sumary of water-quality data for samples collected from the three principal aquifers in the Fond du Lac Indian Reservation Continued

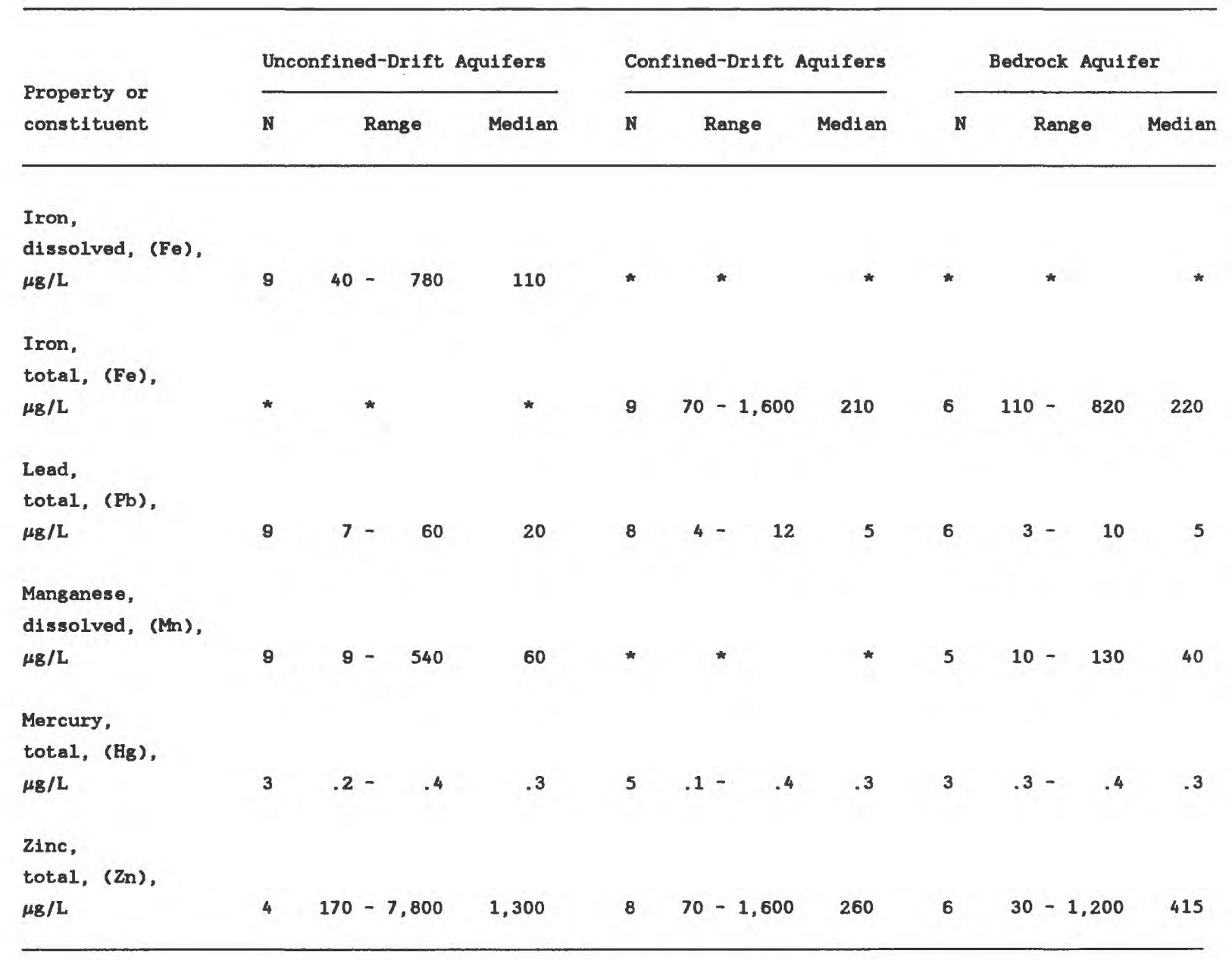


Alkalinity was lower in samples from the unconfined-drift aquifers (median value 66 milligrams per liter $(\mathrm{mg} / \mathrm{L})$ as calcium carbonate) than in samples from the confined-drift and bedrock aquifers, where the median values were $150 \mathrm{mg} / \mathrm{L}$ (table 2). Alkalinity may be lower in the unconfined-drift aquifer because of neutralization by the acidity in precipitation that recharges the aquifer. The amount of acidity in precipitation is known to be elevated above background levels because of acid rain (Thornton and others, 1982). Long-term monitoring of the alkalinity, however, is necessary to establish if the potential effects of acid rain on alkalinity are indeed a trend.

Table 3 lists common water-quality constituents and properties, recommended and regulated limits for drinking water established by the USEPA (U.S. Environmental Protection Agency, 1986), the total number of analyses for each constituent or property, and the number of analyses where the constituent or property exceeds the recommended limit. Table 3 also includes brief descriptions of the significance of the physical properties and chemical constituents. The standards in table 3 represent limits specified in the primary and secondary drinking-water standards. The primary standards, which include nitrate and several trace metals, relate to substances that are hazardous to human health. Secondary standards relate to substances that affect aesthetic qualities of the water.

of the constituents analyzed, zinc, manganese, iron, and nitrate exceeded the recommended limits and standards (table 3). The nitrate concentration exceeded the standard limit at one well completed in an unconfined-drift aquifer. The high zinc concentration most likely was due to contamination from the we11 casing, which sometimes occurs in wells constructed of galvanized iron. The locations of sampling sites where manganese, iron, and nitrate concentrations exceeded the recommended limits and standards are shown in figure 18.

Manganese and, to a lesser extent, iron concentrations exceeded the recommended limits in samples collected from wells completed in the unconfined-drift aquifer. Manganese concentrations also were high in most samples from wells in the confined-drift aquifer and in samples from two wells in the bedrock aquifer along the southern boundary of the study area (fig. 18).

Manganese can cause problems in the aesthetic quality of domestic water supplies. For instance, articles of clothing may become discolored if laundered in water having elevated manganese concentrations. Manganese also can affect the taste of water and of beverages such as coffee or tea made from he water. Manganese is rarely present in drinking-water supplies at highenough concentrations to cause health problems to humans. Iron is similar to manganese in terms of its effects on aesthetic quality. Iron also can cause stains on laundered clothing and unpleasant tastes. Zinc can produce unpleasant tastes and a milky appearance in the water. 


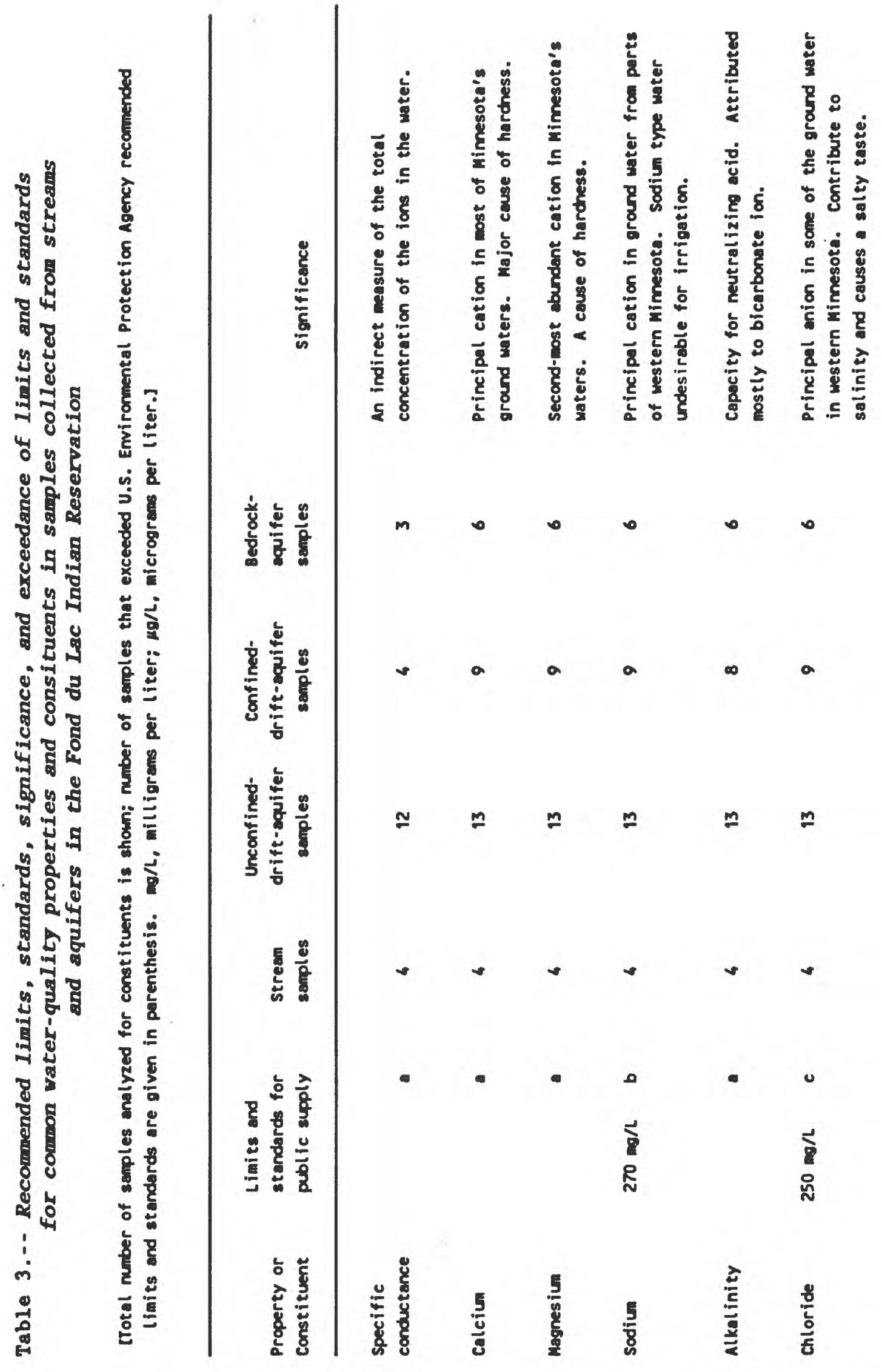




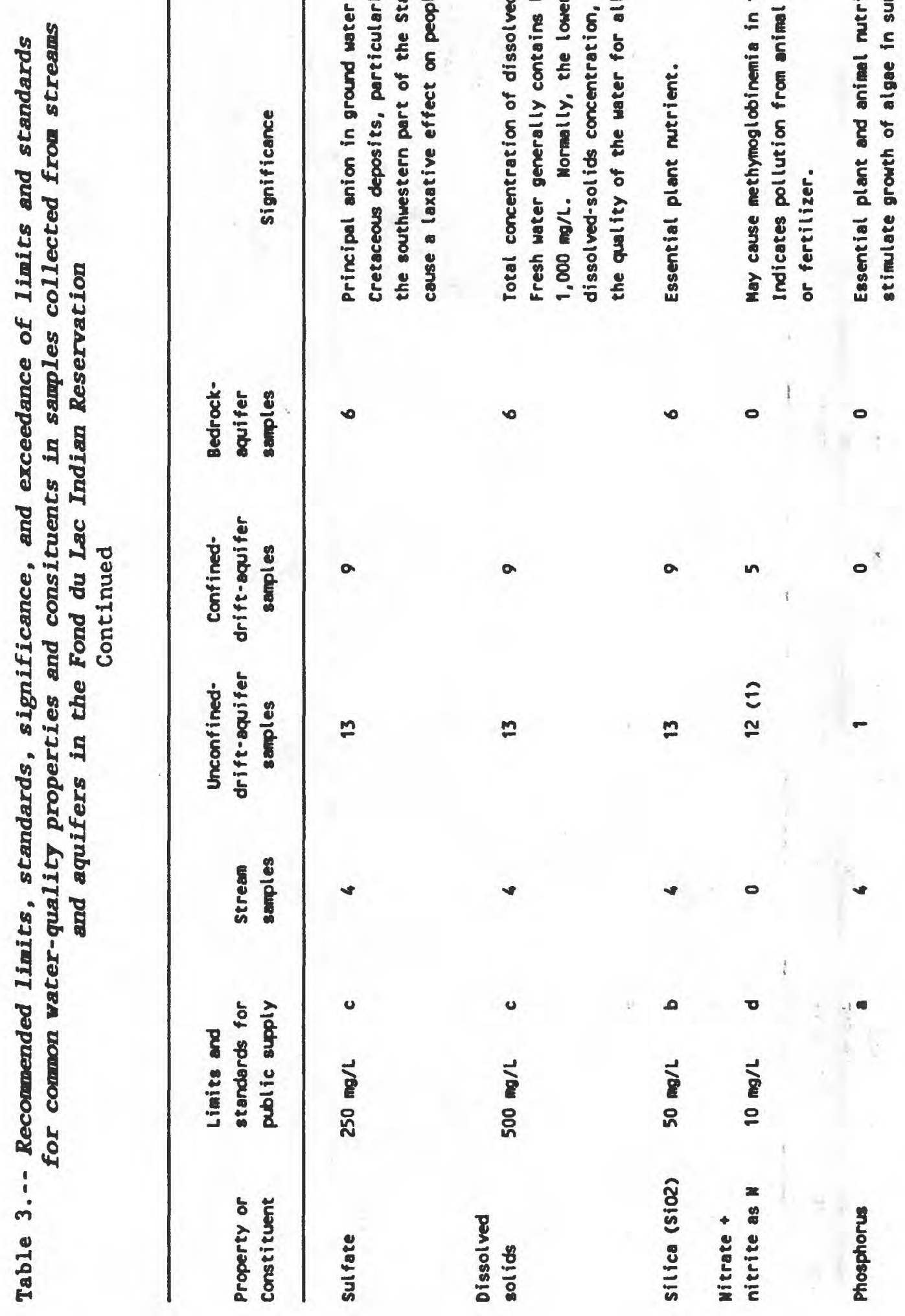




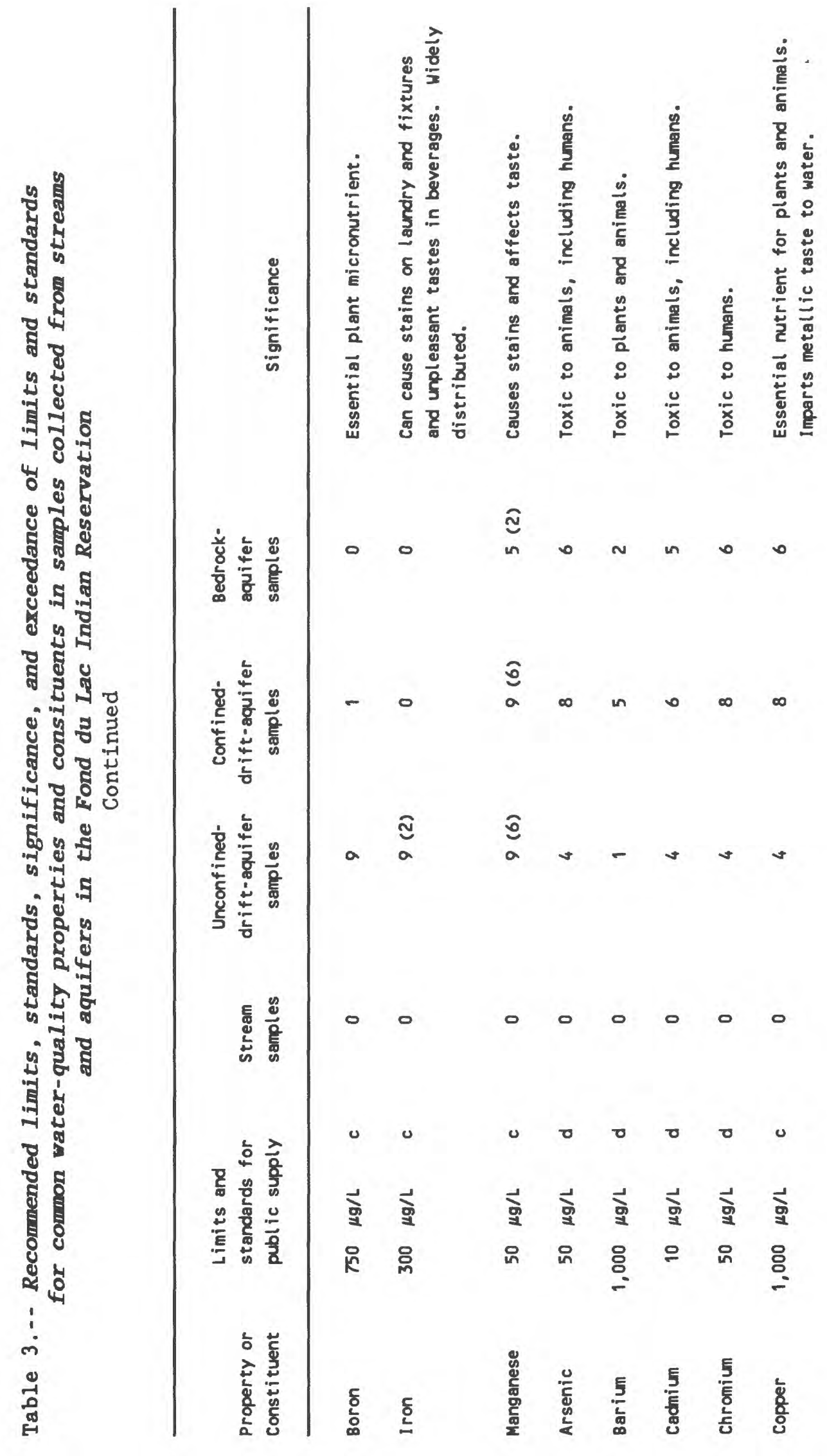




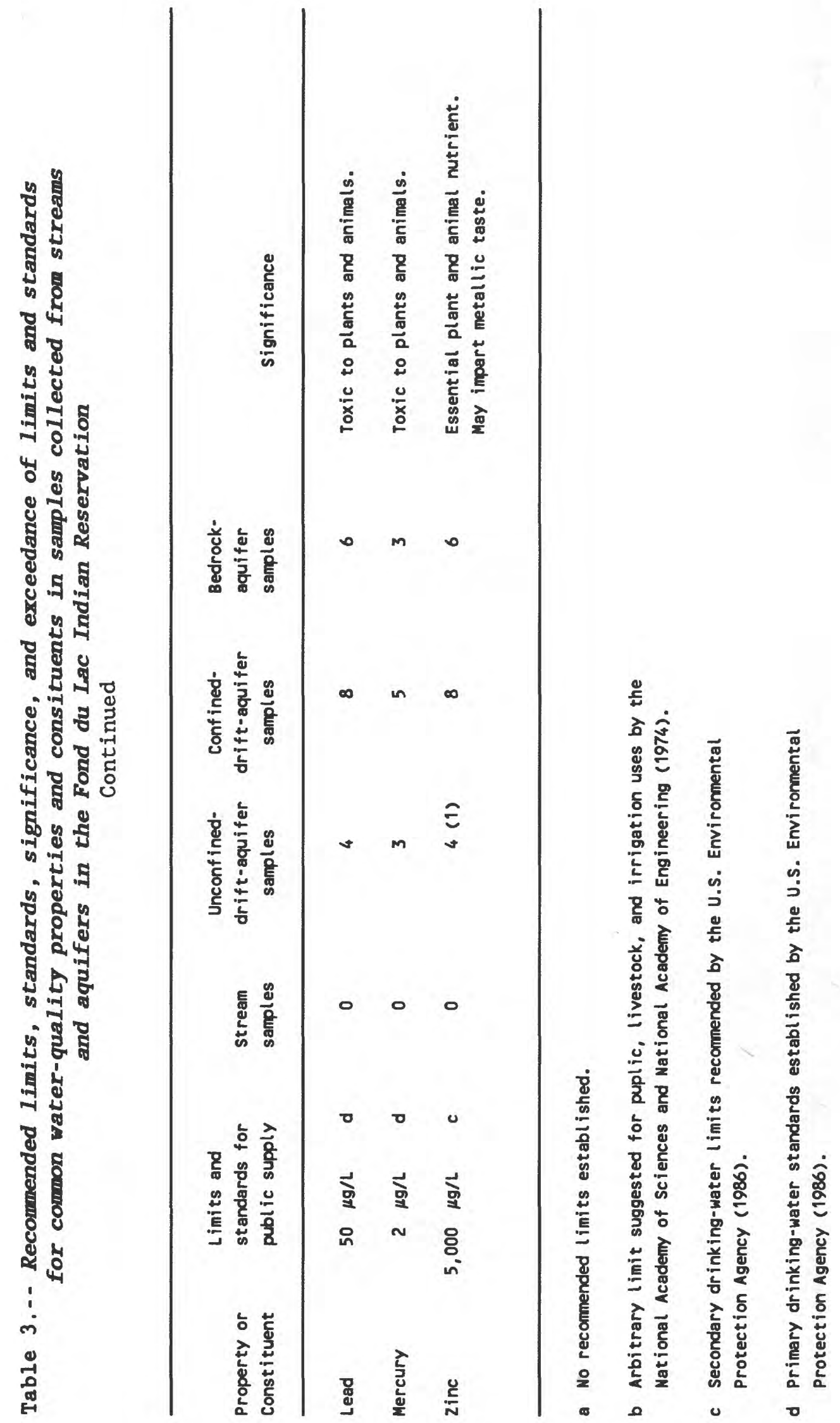




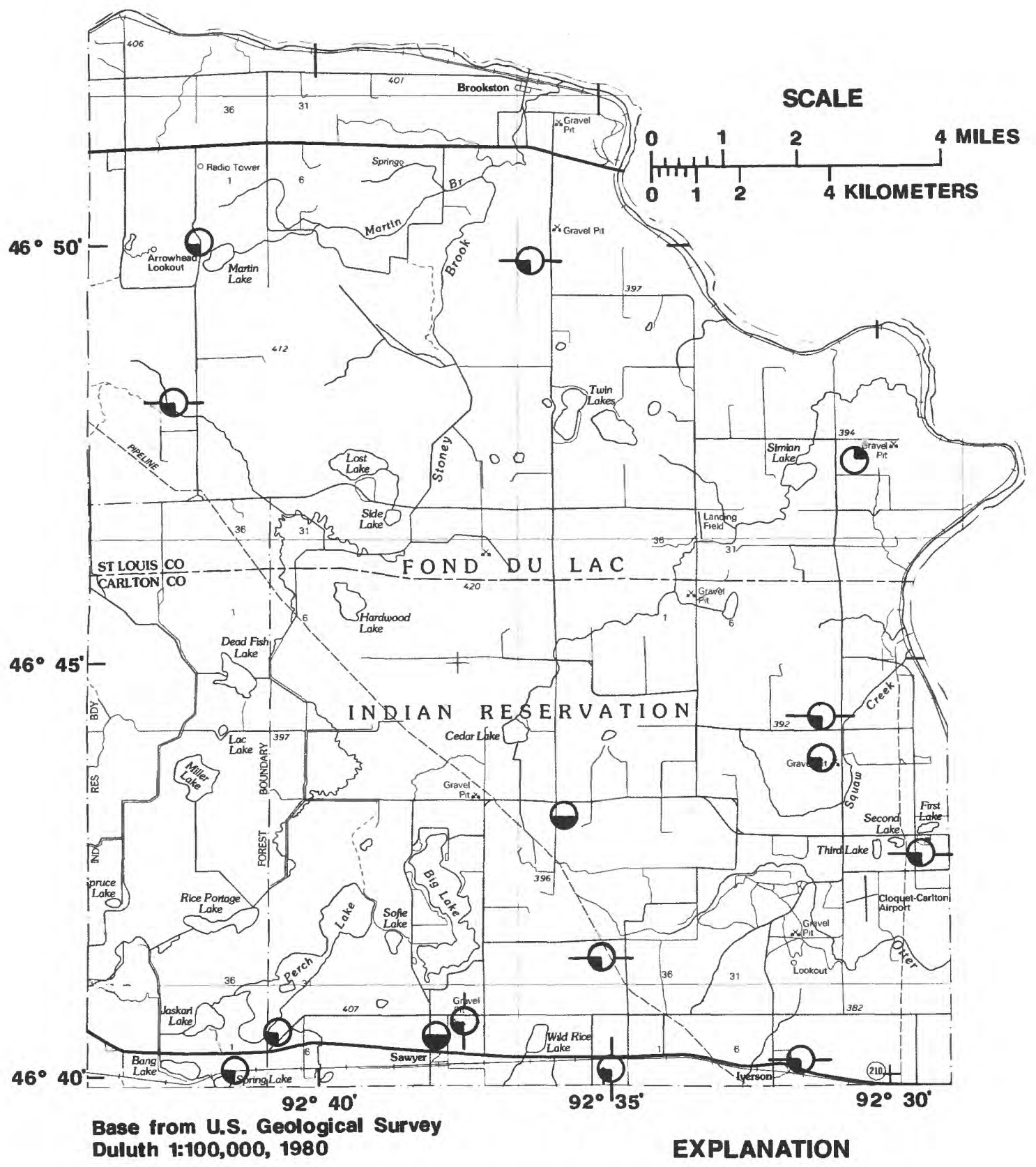
Well in unconfined-drift aquifer
( Nitrate
-Well in confined-drift aquifer
Iron
$\uparrow$ Well in bedrock aquifer
() Manganese

Figure 18. -- Location of wells in the Fond Du Lac Indian Reservation where concentrations of constituents exceed recommended limits and standards for drinking water established by the U.S. Environmental Protection Agency. 
Standards for nitrate and lead concentrations are established by the primary drinking-water regulations, as exceedance of the standards can cause adverse health effects. Elevated nitrate concentrations in drinking water can hinder the transfer of oxygen in the blood of infants. This condition can be very serious and, occasionally, fatal. Lead is well known for its toxicity, particularly for young children. Elevated concentrations of lead in water supplies, however, are uncommon. Corrosion of pipes and soldered joints generally is the source of high concentrations of lead rather than the rawwater supply.

\section{SUMMARY}

The Fond du Lac Indian Reservation includes about 100,000 acres in eastcentral Minnesota. Water resources in the Reservation consist of ground water in glacial-drift and bedrock aquifers and surface water in lakes and rivers. The ground-water resources meet the current water-supply needs of the inhabitants of the Reservation. The surface-water resources provide invaluable ecological, recreational and aesthetic benefits to the physical environment of the Reservation.

Confined sand-and-gravel aquifers are the major source of water supply for the Reservation. These aquifers occur as sand and gravel lenses of variable size that occur discontinuously throughout the Reservation. Unconfined sand-and-gravel aquifers in the southeastern part of the Reservation provide domestic water supplies to a small number of inhabitants. The crystalline bedrock aquifer that underlies the glacial drift has become progressively more important as a source of domestic supply during the past fifteen years.

Surface water in the Reservation drains from four basins. Stoney Brook, which is the major stream, drains a watershed that includes three fourths of the Reservation. The mean flow of stoney Brook is $82 \mathrm{ft}^{3} / \mathrm{s}$. Most lakes in the Reservation are small in surface area and shallow. Big Lake, which is one of the largest lakes, is the most developed for recreational use and lakeshore homes.

Quality of the ground water generally is acceptable for domestic use; it meets most of the recommended limits and standards established by the U.S. Environmental Protection Agency for drinking water. The concentration of manganese and, to a lesser extent, iron, two constituents that affect aesthetic properties of water, exceeded the standard in 15 water samples collected from wells in the glacial-drift and bedrock aquifers. Nitrate and lead concentrations, which adversely affect human health, exceeded the recommended standard in water samples collected from two wells completed in the unconfined-drift aquifers. Quality of surface water in the Reservation is suitable for aquatic habitat. 
Akin, P. D., and Jones, J. R., 1952, Geology and ground-water resources of the Cloquet area, Car1ton County, Minnesota: Minnesota Department of Conservation Bulletin No. 6 .

Anderson, H. W., 1986, Hydrogeologic and water-quality characteristics of crystalline-rock aquifers of Archean and Proterozoic age, Minnesota: U.S. Geological Survey Water Resources Investigations Report 86-4033, 3 plates.

Arrowhead Regional Development Commission, 1981, Fond du Lac Resource Information and Development Plan: Arrowhead Regional Development Commission, $40 \mathrm{p}$.

Eng, M. T., 1979, An evaluation of surficial geology and peat resources, S.W. St. Louis County, Minnesota: Minnesota Department of National Resources.

Fishman, M. J. and Friedman, L. C., 1985, Methods for determination of substances in water and fluvial sediments: U. S. Geological Survey OpenFile Report 85-495, 709 p.

Greeson, P. E., Ehlke, T. A., Irwin, G. A., Lium, B. W., and Slack, K. V., 1979, Methods for the collection and analysis of aquatic biological and microbiological samples: U. S. Geological Survey Techniques of WaterResources Investigations, book 5, chap. A4, $332 \mathrm{p}$.

Heath, R. C., 1983, Basic ground-water hydrology: U. S. Geological Survey Water-Supply Paper 2220, 84 p.

Helgesen, J. D., 1977, Ground-water appraisal of the Pineland Sands area, central Minnesota: U.S. Geological Survey Water-Resources Investigations Report 77-102, $49 \mathrm{p}$.

Hem, J. D., 1986, Study and interpretation of the chemical characteristics of natural water: U.S. Geological Survey Water-Supply Paper 2254 (3rd ed.), $263 \mathrm{p}$.

Leverett, Frank, 1929, Moraines and shorelines of the Lake Superior Basin: U.S. Geological Survey Professional Paper 154- A, p 1-72.

1932, Quaternary Geology of Minnesota and parts of Adjacent States: U.S. Geological Survey Professional Paper 161, p 51- 55.

Lindholm, G. F., Ericson, D. W., Broussard, W. L., and Hult, M. F., 1979, Water resources of the St. Louis River watershed, northeastern Minnesota: U.S. Geological Survey Hydrologic Investigations Atlas, HA-586, $\underline{3}$ plates, Scale 1.

Miller, R. T., 1982, Appraisal of the Pelican River sand-plain, western Minnesota: U.S. Geological Survey Open-File Report 82- 347, 44 p.

Morey, G. B., and Ojakangas, R. W., 1970, Sedimentology of the Middle Precambrian Thomson Formation, east-central Minnesota: Minnesota Geological Survey, Report of Investigations 13, $32 \mathrm{p}$.

Myette, C. F., 1985, Appraisal of the sand-plain aquifers in Carlton, Kanabec, and Pine Counties, east-central Minnesota: U.S. Geological Survey WaterResources Investigations Report 85-4334, 66 p.

National Academy of Sciences, National Academy of Engineering, 1974, Water quality criteria, 1972: U.S. Government Printing Office, Washington, D.C., $594 \mathrm{p}$.

Schwartz, G. M., 1949, The Geology of the Duluth metropolitan area: Minnesota Geological Survey Bulletin 33, p. 106-107.

Sims, P. K., and Morey, G. B., 1972, Geology of Minnesota, A Centennia1 Volume: Minnesota Geological Survey, 632 p. 


\section{REFERENCES - - Continued}

Solley, W. B., Chase, E. B., and Mann, W. B., 1983, Estimated use of water in the United States in 1980: U.S. Geological and Natural History Survey, v. 4, p 1-24.

Thie1, G. A., 1947, The geology and underground waters of northeastern Minnesota: Minnesota Geological Survey Bulletin No. 32, 247 p.

Thornton, David J., Heiskary, Steven A., Payer, Ronald D., and Matta, John, 1982, Acid precipitation in Minnesota, Report to the Legislative Commission on Minnesota Resources: Minnesota Pollution Control Agency, $332 \mathrm{p}$. University of Minnesota Agricultural Experiment Station, 1977, Minnesota Soil Atlas, Duluth Sheet, Miscellaneous Report 148-1977.

U.S. Environmental Protection Agency, 1986, Quality criteria for water 1986: EPA-440/5-86-001.

Winche11, N. H., 1899, The Geology of Minnesota: Minnesota Geological and Natural History Survey, v. 4, p. 1-24.

Wright, H. E., 1956, Glacial geology of eastern Minnesota: in Schwastz, G. M., and Wright, H. E., eds., Field Trip No. 3, Glacial geology of eastern Minnesota: Geological Society of America, $107 \mathrm{p}$.

Wright, H. E., Mattson, L. A., and Thomas, J. A., 1970, Geology of the Cloquet quadrangle, Carlton County, Minnesota: Minnesota Geological Survey Geological Map GM-3 (with text), 30

Wright, H. E., 1973, Tunnel valleys, glacial surges and subglacial hydrology of the Superior Lobe, Minnesota: Geological Society of America, Memoir $136,276 \mathrm{p}$. 